\title{
鉄鎆のバナジウムアタック試験法*
}

\author{
宮川大 海**
}

\section{Testing Method of Vanadium Pentoxide Attack of Steels}

\section{1. 緒言}

重油を燃烧する熱機関などでは最近燃料中の不純物が 各方面から問題になつているが，経済性の見地からある 程度の低質油の使用も避けられない場合もあり, また各 種熱機関の温度も最近をすをす高くなる傾向にある.

$\mathrm{V}, \mathrm{Na}, \mathrm{S}$ などの含有量の多い $\mathrm{C}$ 重油などを使用する と, 周知のとおりバナジウムアタックと呼ばれる加速的 な高温腐食が燃焼ガスに触れる高温部材に 起こりやす く，したがつて高温強度と耐バナジゥムアタック性とを か敉储光た耐熱材料の開発ならびに各種の防食対策の確 立が急がれている.

材料の耐バナジウムアタック性を評価するためには， 現在までに国の内外で種々の試験法が試みられている1). そのうち実㙨試験や燃烧試験は実際の使用状態に近いと いう点で信頼性の高い試験法であるが，設備や燃料また 人件費などに多額の費用を要する。一方浸漬試験や塗布 試験などの实験室的な加速試駼は手軽に行ないうる点で 実用性は高いが，このような加速試験によつて得られた データをそのまま実際の場合に適用しうるかどうかにつ いては問题が残る。また高温腐食現象は複雑で考虑すべ き試験条件も多岐にわたるなどのため, 上記のような各 種の試験法によつてえられた試駼結果間の関連性も必ら ずしも明確ではない。したがつて耐バナジウムアック性 の評洒のための適正かつ実用性に富む試騟法はをだ確立 されていないように思われる.

このような現状にかんがみ，日本学術振興会耐熱金属 材料研究第 123 委員会では, 第 5 (高温腐食) 分科会が 中心となり, 昭和 44 年度ならびに 45 年度において, バ ナジウムアタック試駼泣に関する共同研究を実施した. この共同研究では適当な共通の供試材を選定し，これを 用いて参加機関が種々の試駼法で試験を行ない, 相互の データをつき合わせて各試験法間の関連性を明らかにす るとともに，できうれば最も適正かつ実用性に富む試験 法を見出すことを目的とした. 本研究の結果はすでに同

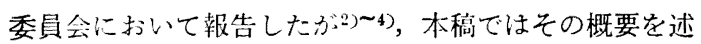
ベてご参考に供したい.

\section{Ohmi Miyagawa}

\section{2. 供試材および試験方法}

\section{$2 \cdot 1$ 供試材}

研究の成果をあげるためには供試材の適否がまず第一 の要件であるが，供試材は耐食性がなるべく段階的に相 違し, かつ入手の容易さや実用面などを考えて現用の代 表的な材料で，できうれば合金元素の影響がわかるよう なものという見地から慎重に検討された。その結果表 1 に示すような 5 種類の合金が選ばれた・試験片は! $16 \mathrm{~mm}$ $\phi$ の丸棒か, 厚さ $4 \mathrm{~mm}$, 幅 $30 \mathrm{~mm}$ の帯板のいずれか から採取することとし, 参加各機関の希望に忍じてこれ らを配布した．熱処理は配布前に一括して行なわれた。

\section{$2 \cdot 2$ 加速試験の試験法と試験条件}

\section{$2 \cdot 2 \cdot 1$ 昭和 44 年度の方針}

多数の機関が参加して行なう共同研究においては試験 条件をどのように統一するかがむずかしい問題であるの で，昭和 44 年度は手始めとしてとりあえず各機関が現 に実施しあるいは実施可能な範囲の試験法と試験条件と によつて試験を行なうこととし, 試験温度と時間, 合成 灰の組成などの主要な条件だけを統一することとした。 そして試験温度と時間は $900^{\circ} \mathrm{C}-1 \mathrm{hr}$ および $800^{\circ} \mathrm{C}-20$ $\mathrm{hr}$ ，合成灰の組成は腐食が著しいと考えられる $85 \%$ $\mathrm{V}_{2} \mathrm{O}_{5}+15 \% \mathrm{Na}_{2} \mathrm{SO}_{4}{ }^{5}$ ) とした. な书予備実験6) の結果, $\mathrm{V}_{2} \mathrm{O}_{5}$ と $\mathrm{Na}_{2} \mathrm{SO}_{4}$ の銘柄によつて全浸漬試験の腐食減量 に多少の相違が認められ，このような傾向は特級品のほ うが一級品より少なかつた。それで両者とも特級品を用 いることとしたが，銘柄の統一は䀠入先との関係などを 考光てあえて行なわなかつた・ルツボの種類についても 同様である.

$2 \cdot 2 \cdot 2$ 昭和 44 年度参加各機関の試験法と試験条件

(1) 全浸漬および半浸漬試験

全浸漬試験は表 2 に概略を示すような試駼条件のもと で 15 機関で行なわれた. 以下大交字のアルフォベット で機関（順不同）を，数字で試験法の種類を表わす。す なわち 1 は全浸漬試験， 2 は半浸漬試験，3〜6はとれ

* 昭和 46 年 5 月 6 日 受付（依頼技術資料）

** 東京都立大学工学部 工博 日本学術振興会 耐熱金属材料研究第 123 委員会 第 5 分科会主査 
表 1 供試材の化学組成と熱処理条件

\begin{tabular}{|c|c|c|c|c|c|c|c|c|c|c|c|}
\hline & & & & 化 & 学 & 組 & & 㦴 $(\%)$ & & & \\
\hline & C & $\mathrm{Si}$ & $\mathrm{Mn}$ & $\mathrm{P}$ & $\mathrm{S}$ & $\mathrm{Cr}$ & $\mathrm{Ni}$ & Co & Mo & その他 & 然処理条 作 \\
\hline $\begin{array}{l}\text { SUS 27 } \\
(304)\end{array}$ & 0.07 & 0.65 & $1 \cdot 75$ & 0.032 & $0 \cdot 006$ & $18 \cdot 41$ & $8 \cdot 57$ & - & - & & 溶 体 化 \\
\hline $\begin{array}{l}\text { SUS 32 } \\
(316)\end{array}$ & 0.06 & $0 \cdot 70$ & $1 \cdot 56$ & 0.032 & 0.006 & $17 \cdot 50$ & $12 \cdot 01$ & - & $2 \cdot 43$ & & " \\
\hline $\begin{array}{c}\mid \operatorname{SUS} 41 \\
(309 \mathrm{~S})\end{array}$ & 0.07 & 0.54 & $1 \cdot 72$ & 0.025 & 0.008 & $22 \cdot 55$ & $14 \cdot 32$ & - & - & & " \\
\hline S 509 & 0.43 & 0.47 & $1 \cdot 51$ & 0.019 & 0.023 & $19 \cdot 98$ & $19 \cdot 79$ & $20 \cdot 09$ & $3 \cdot 92$ & $\begin{array}{l}\mathrm{Nb} 4 \cdot 10 \quad \mathrm{~W} 3 \cdot 98 \\
\mathrm{Cu} 0 \cdot 06\end{array}$ & $\mid \begin{array}{r}180^{\circ} \mathrm{G} \times 1 \mathrm{hrWQ} \\
760^{\circ} \mathrm{G} \times 16 \mathrm{hrAC}\end{array}$ \\
\hline $\begin{array}{c}\text { Inconel } \\
\mathrm{X}\end{array}$ & 0.05 & $0 \cdot 10$ & $0 \cdot 15$ & 0.003 & 0.002 & $15 \cdot 20$ & $74 \cdot 05$ & - & - & $\begin{array}{cl}\mathrm{Nb}+\mathrm{Ta} & 0.86 \\
\mathrm{Al} & 0.89 \\
\mathrm{Ti} & 2.60 \\
\mathrm{Zr} & 0.01 \\
\mathrm{~B} & 0.0066 \\
\mathrm{Cu} & 0.02 \\
\mathrm{Fe} & 5.92\end{array}$ & $\begin{array}{r}1140^{\circ} \mathrm{C} \times 2 \mathrm{hrAC} \\
845^{\circ} \mathrm{C} \times 24 \mathrm{hrAC} \\
705^{\circ} \mathrm{C} \times 20 \mathrm{hrAC}\end{array}$ \\
\hline
\end{tabular}

ぞれ塗布試験，交互浔漬試験，燃焼試験，および酸素消 費量試験である. 半浸漬試験は 1 機関で行なわれ，その 条件を表 2 にあわせて示す.

(2) 塗布試験

塗布試験は表 3 に示すように 5 機関で行なわれた. 試 験片は D-3 試験を除いていずれも板状で，表示のよう な種々の方法でだいたい 5〜20 $\mathrm{mg} / \mathrm{cm}^{2}$ の合成灰を全面 塗布または片面散布している.

\section{(4) 交互浸漬試験}

交互浸漬試験は 2 件行なわれ，両試験とも $12 \phi \times 12$ の円柱状試験片を用いているが，加熱法は異なる。すな わち H-4 試験では試験片を溶融灰中へ $15 \mathrm{~min}$ 間浸漬 したのち、ルツボを下へさげ試験片はそのままの位置で $15 \mathrm{~min}$ 間加熱することを繰り返している. これに対し J-4 試験では試験片を 溶融灰中に 2〜3 sec 間浸漬した のち, 灰の表面より少し高い位置で $15 \mathrm{~min}$ 間加熱し, 以後これを繰り返す通常の方法7 9) 採用している.

\section{(5) 燃焼試験}

燃焼試験では装置の関倸などで試験条件の統一はさら に困難であるので, 温度や時間, 燃料組成などの基本的 条件も統一せず各機関が現に行ないつつある条件で実施 された. 件数は 5 件で，それらの試験条件の概略を表 4 に, 試験装置の一例を図 1 に示す. G-5〜P-5 試験では この図のように燃焼室の後方に試験部を設けた横型の装 置を用い, Q-5 試験では燃焼室内の下部に試験片をお き，その横手に燃焼ガスの出口を設けた堅型の装置を用 いている.

\section{$2 \cdot 2 \cdot 3$ 昭和 45 年度の方針}

後述のような昭和 44 年度の研究結果にもとういて十 分審議した結果，45 年度は前年度調製した 5 種類の供
試材をひき続き使用することとし，前年度燃焼試騟結果 との对応のよかつた塗布試験に一応の主眼をおき，かつ 燃焼試験を除く各加速試験においては試験条件をなるべ く細かく統一して研究を進めることとした。

まず加速試験に共通な試騟温度および時間は, 前年度 は $900^{\circ} \mathrm{C}-1 \mathrm{hr}$ と $800^{\circ} \mathrm{C}-20 \mathrm{hr}$ であつたが，この両条件 でえられる腐食減量は後者の汪うがはるかに多いこと， たま $1 \mathrm{hr}$ という短時間の試験では試験開始直後の温度 変動などのため誤差が入りやすいことなどを考虑して， 45 年度は $900^{\circ} \mathrm{C}-3 \mathrm{hr}$ および $800^{\circ} \mathrm{C}-20 \mathrm{hr}$ を採用した。 また合成灰の組成は一応前年度と同じにした。これら以 外の各試験法における試験条件についてはそれぞれ次項 で述べる.

$2 \cdot 2 \cdot 4$ 昭和 45 年度参加各機関の試験法と試験条件

（1）全浸漬および半浸漬試験

表 5 に 45 年度の全浸漬および半浸漬試験の試験条件 を示す. 45 年度の試験については小文字のアルフォベ ットを機関の記号とした. 45 年度は試験条件を表示の ように細かく統一したが，試験には合計 3 機関が参加し たのみであつた。

(2) 塗布試験

前述のように 45 年度はこの試験に主眼をおいたため 17 機関が参加した。試験条件は以下のようにして 細か く統一した・宁なわち, 試験片の形状寸法は供試材の残 量をも考えて $15 \phi \times 3,25 \times 15 \times 3.5$ のいずれかとし, 機械加工後 5500 ( $¥ 03$ ) 前後まで全面をエメリ一研摩す ることにした. 参加機関のうち後者の角型板状試験片を 用いたのは $\mathrm{o}, \mathrm{k}, \mathrm{n}$ の 3 機関のみであつた。

合成灰の塗布方法は大別して合成灰をそのまま試験片 に塗布するいわゆる混合塩塗布法と, 溶融合成灰中に試 
浆 2 全浸漬および半浸清試験の条件（昭和 44 年度）

\begin{tabular}{|c|c|c|c|c|c|c|c|c|c|c|}
\hline 試 & $\begin{array}{c}\text { 試験片形 } \\
\text { 状 寸 法 } \\
(\mathrm{mm})\end{array}$ & $\begin{array}{l}\text { 仕上方 } \\
\text { 法 } \\
\left(\begin{array}{l}\text { 表面 } \\
\text { 粗さ }\end{array}\right)\end{array}$ & $\left.\mid \begin{array}{c}\text { ルッボ } \\
\text { 形状寸法 } \\
(\mathrm{mm}) \\
(\text { 上径-下 } \\
\text { 径一滈さ }\end{array}\right)$ & $\begin{array}{l}\text { ルツボ } \\
\text { 材 質 }\end{array}$ & $\begin{array}{l}1 \text { 個のル } \\
\text { \%ボ中の } \\
\text { 合成灰の } \\
\text { 量, 溶融 } \\
\text { 灰の深さ }\end{array}$ & $\begin{array}{l}\text { 試験 } \\
\text { 片の } \\
\text { おき } \\
\text { 方 }\end{array}$ & $\begin{array}{l}1 \text { 個の } \\
\text { ルツボ } \\
\text { 中の試 } \\
\text { 跧片数 }\end{array}$ & 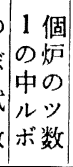 & 脱スケール法 & $\begin{array}{l}\text { 炬の型, 内のり } \\
\text { 寸法 } \\
(\mathrm{mm})\end{array}$ \\
\hline$A-1$ & $12 \phi \times 12$ & $\nabla \nabla \nabla$ & $\mid \begin{array}{cc}51 \phi & 41 \\
\text { 容量 } 50 \mathrm{cc}\end{array}$ & $\begin{array}{l}\text { SSA-H } \\
B-2\end{array}$ & $50 \mathrm{~g}$ & $\begin{array}{l}\text { たて } \\
\text { おき }\end{array}$ & 1 & 3 & $30 \% \mathrm{HNO}_{3}$ 中沸騰 & $\begin{array}{l}\text { 二クロ } \\
110 \phi \times 6 \text { 横型管 }\end{array}$ \\
\hline B-1 & $12 \phi \times 12$ & 旋 & $\begin{array}{l}47 \phi-25 \\
\phi-40\end{array}$ & SC.P. & $37 \cdot 6 \mathrm{~g}$ & " & 1 & 7 & $\begin{array}{l}\mathrm{NaOH} 40 \%+\mathrm{Na}_{2} \\
\mathrm{CO}_{3} 60 \% \\
\text { 電解 }\left(600^{\circ} \mathrm{C}\right)\end{array}$ & $\begin{array}{l}\text { シリコニット箱型 } \\
150 \mathrm{~W} \times 500 \mathrm{D} \\
\times 150 \mathrm{H}\end{array}$ \\
\hline C -1 & $15 \phi \times 13$ & $\begin{array}{l}\text { エメリ } \\
\Xi 03\end{array}$ & $\begin{array}{l}54 \phi 43 \\
\text { 容量 } 50 \mathrm{cc}\end{array}$ & $\mid$\begin{tabular}{l|} 
SSA-H \\
$B-2$
\end{tabular} & $47 \mathrm{~g}$ & $\begin{array}{l}\text { よこ } \\
\text { おき }\end{array}$ & 1 & 3 & $\begin{array}{l}\text { 浸漬 } \\
\mathrm{NaH}\end{array}$ & $\begin{array}{l}\text { エレマ横型 } \\
200 \mathrm{~W} \times 400 \mathrm{D} \\
\times 150 \mathrm{H}\end{array}$ \\
\hline D-1 & $15 \phi \times 10$ & $\nabla \nabla \nabla$ & $54 \phi 42$ & $\begin{array}{l}\text { SSA-S } \\
\text { SSA-H }\end{array}$ & $30 \mathrm{~g}$ & $\begin{array}{l}\text { たて } \\
\text { おき }\end{array}$ & 1 & 5 & 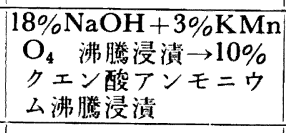 & $\begin{array}{l}\text { エレマ横型 } \\
200 \mathrm{~W} \times 400 \mathrm{D} \\
\times 150 \mathrm{H}\end{array}$ \\
\hline$E-1$ & $10 \phi \times 20$ & $\nabla \nabla \nabla$ & $38 \phi 55$ & SSA-H & $\begin{array}{l}30 \mathrm{~g} \\
15 \mathrm{~mm}\end{array}$ & $\begin{array}{l}\text { よこ } \\
\text { お点 }\end{array}$ & 1 & 5 & $\begin{array}{l}\mathrm{NaOH} 50 \mathrm{~g}+\mathrm{KOH} \\
50 \mathrm{~g} \text { 浸漬 }\end{array}$ & $\begin{array}{l}\text { 抵抗線横型管状 } \\
1001000\end{array}$ \\
\hline $\mathbf{F}-1$ & $\mid \begin{array}{l}(15 \sim 16) \\
\phi \times(12 \\
\sim 14)\end{array}$ & $\begin{array}{l}\text { エメリ } \\
\text { こ } \\
=500\end{array}$ & $\begin{array}{cc}53 \phi & 43 \\
\text { 容量 } & 50 \mathrm{cc}\end{array}$ & 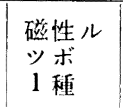 & $30 \mathrm{~g}$ & - & 1 & 5 & $\begin{array}{l}\mathrm{NaOH}+\mathrm{Na}_{2} \mathrm{CO}_{3} \\
\text { 電解 }\end{array}$ & $\begin{array}{l}\text { エレマ横型 } \\
250 \mathrm{~W} \times 800 \mathrm{D} \\
\times 140 \mathrm{H}\end{array}$ \\
\hline$G-1$ & & 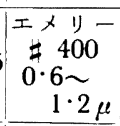 & $\begin{array}{c}44 \phi-22 \\
\phi-55\end{array}$ & $\begin{array}{l}\text { 化学磁 } \\
\text { 器 } \\
\text { C-3 }\end{array}$ & $\begin{array}{l}30 \mathrm{~g} \text { 試 } \\
\text { 料上面よ } \\
り 3 \mathrm{~mm}\end{array}$ & $\begin{array}{l}\text { たてて } \\
\text { おき }\end{array}$ & 1 & 5 & $\begin{array}{l}\mathrm{NaOH} 45 \%+\mathrm{Na}_{2} \\
\mathrm{CO}_{3} 55 \% \text { 電解 }\end{array}$ & $\begin{array}{l}\text { 箱型電気炉 } \\
200 \mathrm{~W} \times 400 \mathrm{D} \\
\times 200 \mathrm{H}\end{array}$ \\
\hline$H-1$ & $12 \phi \times 12$ & $\begin{array}{l}\text { エメリ } \\
\text { ‡04 }\end{array}$ & $\begin{array}{c}54 \phi-30 \\
\phi-43\end{array}$ & $\begin{array}{l}\text { フルミ } \\
\text { ナ }\end{array}$ & $60 \mathrm{~g}$ & - & 1 & 5 & $\begin{array}{l}\mathrm{NaOH} 40 \%+\mathrm{Na}_{2} \\
\mathrm{CO}_{3} 60 \% \text { 電解 }\end{array}$ & $\begin{array}{l}\text { 横型電気炻 } \\
130 \mathrm{~W} \times 600 \mathrm{D} \\
\times 130 \mathrm{H}\end{array}$ \\
\hline I - 1 & $15 \phi \times 10$ & $\begin{array}{l}\text { 而水研 } \\
\text { 摩紙 } \\
\text { No. } 240\end{array}$ & $\begin{array}{l}44 \phi-23 \\
\phi-36\end{array}$ & $\begin{array}{l}\text { SSA } \\
\text { B-1 }\end{array}$ & $30 \mathrm{~g}$ & - & 1 & 5 & $\begin{array}{l}\mathrm{NaOH} 60 \%+\mathrm{Na}_{2} \\
\mathrm{CO}_{3} 40 \% \text { 電解 }\end{array}$ & $\begin{array}{l}\text { シリコニット箱型 } \\
200 \mathrm{~W} \times 310 \mathrm{D} \\
\times 200 \mathrm{H}\end{array}$ \\
\hline $\mathrm{J}-1$ & & $\begin{array}{l}\text { エメリ } \\
\text { No. } 500\end{array}$ & $\begin{array}{c}44 \phi-44 \\
\phi-40\end{array}$ & SSA & $\begin{array}{l}50 \mathrm{~g} \text { 試 } \\
\text { 料上面よ } \\
\text { り } 1 \mathrm{~mm}\end{array}$ & $\begin{array}{l}\text { たてて } \\
\text { お意 }\end{array}$ & 1 & 2 & $\begin{array}{l}\mathrm{NaOH} 40 \%+\mathrm{Na}_{2} \\
\mathrm{CO}_{3} 60 \% \text { 電解 }\end{array}$ & =クロム横型管状 \\
\hline $\mathrm{J}-2$ & " & " & " & " & $10 \mathrm{~g}$ & " & 1 & 2 & " & " \\
\hline $\mathrm{K}-1$ & $15 \phi \times 15$ & $\begin{array}{l}\text { パフ研 } \\
\text { 摩: }\end{array}$ & $\begin{array}{l}46 \phi 53 \\
\text { 容量 } 50 \mathrm{cc}\end{array}$ & SSA-H & $\begin{array}{l}50 \mathrm{~g} \quad 27 \\
\sim 30 \mathrm{~mm}\end{array}$ & $\begin{array}{l}\text { よこ } \\
\text { おき }\end{array}$ & 1 & 6 & " & マッフル炬 $8 \mathrm{KW}$ \\
\hline $\mathrm{L}-1$ & $\begin{array}{l}10 \cdot 5 \dot{\phi} \\
\times 5\end{array}$ & $\begin{array}{l}\text { エメリ } \\
\text { ー }=03\end{array}$ & 容量 $15 \mathrm{cc}$ & $\mid$ 石 英 & $3.53 \mathrm{~g}$ & $\begin{array}{l}\text { たて } \\
\text { おき }\end{array}$ & 1 & 1 & $\underset{\text { 浸清 }}{\mathrm{NaOH}}+1 \% \mathrm{KMnO}_{4}$ & 堅型管状電気炉 \\
\hline $1-1$ & $115 \phi \times 12$ & $\nabla \nabla \nabla$ & $\begin{array}{c}51 \phi 41 \\
\text { 容量 } 50 \mathrm{cc}\end{array}$ & $\begin{array}{l}\text { SSA-H } \\
\text { B }-2\end{array}$ & $\begin{array}{l}50 \mathrm{~g} \text { 試 } \\
\text { 料上面よ } \\
り 8 \mathrm{~mm}\end{array}$ & " & 1 & 1 & $\begin{array}{l}\mathrm{NaOH} 40 \%+\mathrm{Na}_{2} \\
\mathrm{CO}_{3} 60 \% \text { 電解 }\end{array}$ & $\begin{array}{l}\text { 竪型管状電気灯 } \\
80160\end{array}$ \\
\hline$N-1$ & $\begin{array}{l}25 \times 25 \\
\times 3 \\
\text { 板 状 }\end{array}$ & $\begin{array}{l}\text { エメリ } \\
\text { こ } 600\end{array}$ & $\begin{array}{l}53 \phi 43 \\
\text { 容量 } 50 \mathrm{cc}\end{array}$ & $\begin{array}{l}\text { ユランン } \\
\text { ダム } \\
\mathrm{Al}_{2} \mathrm{O}_{3}\end{array}$ & $80 \mathrm{~g}$ & - & 1 & 3 & $\begin{array}{l}\mathrm{NaOH} 55 \%+\mathrm{Na} \\
\mathrm{NO}_{3} 33 \%+\mathrm{NaCl} 18 \\
\%+\mathrm{Na}_{2} \mathrm{CO}_{3} 5 \% \text { 浸 } \\
\text { 漬 } \rightarrow \text { 硝弗酸 } \\
\end{array}$ & $\begin{array}{l}=\text { ク口公横型管状 } \\
68 \phi \times 600\end{array}$ \\
\hline-1 & $\begin{array}{l}15 \phi \times \\
12\end{array}$ & $\begin{array}{l}\text { エメリ } \\
\text { - } 04\end{array}$ & $\begin{array}{l}60 \phi-30 \\
\phi-45\end{array}$ & SSA & $47 \mathrm{~g}$ & $\begin{array}{l}\text { たて } \\
\text { おき }\end{array}$ & 1 & 5 & $\begin{array}{l}\mathrm{NaOH} 40 \%+\mathrm{Na}_{2} \\
\mathrm{CO}_{3} 60 \% \text { 電解 }\end{array}$ & $\begin{array}{l}\text { マッフル灯 } \\
200 W \times 450 \mathrm{D} \\
\times 200 \mathrm{H}\end{array}$ \\
\hline
\end{tabular}


表 3 塗布試験の条件（昭和 44 年度）

\begin{tabular}{|c|c|c|c|c|c|c|c|c|c|}
\hline 試 & $\begin{array}{l}\text { 試験片 } \\
\text { 形状寸 } \\
\text { 法 } \\
(\mathrm{mm})\end{array}$ & $\begin{array}{l}\text { 仕上方法 } \\
\left(\begin{array}{l}\text { 表面粗 } \\
\text { さ }\end{array}\right)\end{array}$ & 合成灰の塗布方法 & $\begin{array}{l}\text { 塗布 量 } \\
\left(\mathrm{mg} / \mathrm{cm}^{2}\right)\end{array}$ & $\begin{array}{l}\text { 試䀦片 } \\
\text { 保拈方法 }\end{array}$ & 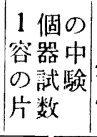 & 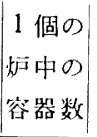 & $\begin{array}{l}\text { 脱スケー } \\
\text { ル法 }\end{array}$ & $\begin{array}{l}\text { 相の型 } \\
\text { 内のり } \\
\text { 寸法 } \\
(\mathrm{mm})\end{array}$ \\
\hline D-3 & $5 \phi \times 6$ & $\nabla \nabla \nabla$ & $\begin{array}{l}\text { 水ガラスを } 7 \text { 倍程度の } \\
\text { 水でうすめた溶液中に } \\
\text { 試験片を渍し, ひろげ } \\
\text { た灰の上におしつけ } \\
\text { る. } 300^{\circ} \mathrm{C} て ゙ \text { 乾燥して } \\
\text { 余分な灰をおとす. }\end{array}$ & 約 20 & $\begin{array}{l}\text { 白金板製のボー } \\
\text { 上上に端面を横 } \\
\text { にしてならべる }\end{array}$ & 5 & 5 & D-1 に同じ & $\begin{array}{l}\text { 横型管 } \\
\text { 状 }\end{array}$ \\
\hline $\mathrm{G}-3$ & $\left(\begin{array}{l}30 \times 12 \\
\times 3\end{array}\right.$ & $\begin{array}{l}\text { エメリー } \\
400 \\
0 \cdot 6 \sim 0.8 \mu\end{array}$ & $\begin{array}{l}\text { クリヤラッカーをうす } \\
\text { く奴り二定量の灰を表 } \\
\text { 面に均等にふりかける }\end{array}$ & 10 & $\begin{array}{l}\text { 化学磁気 G-2 } \\
\text { のボート上にの } \\
\text { せる }\end{array}$ & 1 & 10 & G-1 に同じ & $\begin{array}{l}\text { G-1 } \\
\text { に同じ }\end{array}$ \\
\hline I -3 & $\begin{array}{l}25 \times 25 \\
\times 3 \cdot 8\end{array}$ & $\begin{array}{l}\text { 耐水研摩紙 } \\
\text { No. } 240\end{array}$ & $\begin{array}{l}\text { フルコールでぬらし片 } \\
\text { 面のみに一様に叙布す } \\
\text { る }\end{array}$ & $\begin{array}{l}0 \cdot 3 \\
\left(\begin{array}{l}\text { 全表面 } \\
\text { 積当り }\end{array}\right)\end{array}$ & $\begin{array}{l}\text { SSA ルツボを逆 } \\
\text { にしてその上に } \\
\text { のせる }\end{array}$ & 1 & 5 & I -1 に同じ & $\begin{array}{l}\mathrm{I}-1 \\
\text { に同じ }\end{array}$ \\
\hline$N-3$ & $\begin{array}{l}35 \times 25 \\
\times 3.5\end{array}$ & $\begin{array}{l}\text { エメリー } \\
\sharp 600\end{array}$ & $\begin{array}{l}\text { 合成戻を } 800^{\circ} \mathrm{C} \text { に溶 } \\
\text { 乙の中へ } 3 \mathrm{~min} \text { 間漫 } \\
\text { したのち空冷 }\end{array}$ & 5 & $\begin{array}{l}\text { 試験片の孔に二 } \\
\text { クロム線のフッ } \\
\text { クをかけ 70mm } \\
\text { 間隔につるす }\end{array}$ & - & $\begin{array}{l}\text { 試験 } \\
\text { 片 } \\
3\end{array}$ & N-1に同じ & $\begin{array}{l}\mathrm{N}-1 \\
\text { に同じ }\end{array}$ \\
\hline $\mathrm{O}-3$ & $\begin{array}{r}50 \times 8 \\
\times 3.5\end{array}$ & $\begin{array}{c}\nabla \nabla \nabla \\
6 \mathrm{~s}\end{array}$ & 上面に散有する & $\begin{array}{l}7 \cdot 3 \\
21 \cdot 7 \\
\left(\begin{array}{l}\text { 全表面 } \\
\text { 積当り }\end{array}\right)\end{array}$ & $\begin{array}{l}\text { フルミナボート } \\
\text { 中におさめる }\end{array}$ & 1 & 10 & $\begin{array}{l}\text { ワイヤブラシ } \\
\text { でこする } \\
\text { ンマでたたく } \\
\text { マワイヤブラ } \\
\text { シでこする }\end{array}$ & $\mid \begin{array}{l}\text { 横型電 } \\
\text { 気炉 } \\
100 \phi \times \\
1000\end{array}$ \\
\hline
\end{tabular}

表 4 燃 㜔 試 験 の 条 件 (昭和 44,45 年度)

\begin{tabular}{|c|c|c|c|c|c|c|c|c|c|c|}
\hline \multirow{2}{*}{ 試験 } & \multirow{2}{*}{$\begin{array}{c}\text { 試験片の寸法 } \\
(\mathrm{mm})\end{array}$} & \multicolumn{2}{|r|}{ 重 油 } & \multicolumn{3}{|c|}{ 組 成 } & \multirow{2}{*}{$-\begin{array}{c}\text { 試験温度 } \\
\left({ }^{\circ} \mathrm{C}\right)\end{array}$} & \multirow{2}{*}{$\begin{array}{c}\text { 試 験 } \\
\text { 時 間 } \\
(\mathrm{hr})\end{array}$} & \multirow{2}{*}{$\begin{array}{l}\text { ガ } \\
\text { 流 速 } \\
(\mathrm{m} / \mathrm{sec})\end{array}$} & \multirow{2}{*}{$\begin{array}{l}\text { 燃料消 } \\
\text { 費量 } \\
(l / \mathrm{hr})\end{array}$} \\
\hline & & $V(p p m)$ & $\mathrm{Na}(\mathrm{ppm})$ & $\mathrm{S}(\%)$ & $\begin{array}{c}\text { の 他 } \\
(\mathrm{ppm})\end{array}$ & 灰分 $(\%)$ & & & & \\
\hline$G-5$ & $56 \times 12 \times 3$ & 32 & $8 \cdot 8$ & $2 \cdot 45$ & - & - & $\begin{array}{l}730, \quad 750 \\
780\end{array}$ & 100 & 30 & $5 \sim 8$ \\
\hline K-5 & $\begin{array}{l}\text { 外径 } 29 \text {, 内径 } \\
15, \text { 厚さ } 3 \cdot 8\end{array}$ & 72 & 12 & $2 \cdot 46$ & $\begin{array}{ll}\mathrm{Zn} & 0.9 \\
\mathrm{Mg} & 0.6\end{array}$ & 0.01 & 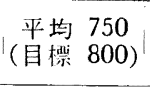 & 100 & 150 & 80 \\
\hline$O-5$ & $\begin{array}{l}\text { 外径 } 25, \text { 内径 } \\
4, \text { 厚 } 3\end{array}$ & $\begin{array}{c}\mathrm{A} \text { 恶油 }+ \\
\left(\mathrm{V}_{2} \mathrm{O}_{5}\right.\end{array}$ & $\begin{array}{l}-\mathrm{V}_{2} \mathrm{O}_{5} 357 \mathrm{pp} \\
: \mathrm{Na}_{2} \mathrm{SO}_{4}=\end{array}$ & $\begin{array}{l}\mathrm{m}+\mathrm{Na}_{2} \\
35: 15)\end{array}$ & $\mathrm{O}_{4} 63 \mathrm{ppm}$ & & $826 \sim 878$ & 50 & 20 & $0 \cdot 4$ \\
\hline$P-5$ & $\begin{array}{l}55 \times 25 \times 3 \cdot 5 \\
15 \phi \times 40\end{array}$ & 80 & 12 & $2 \cdot 87$ & $\mathrm{Ni} 23$ & $0 \cdot 02$ & 900 & 30 & $44 \cdot 5$ & 55 \\
\hline$Q-5$ & $30 \times 30 \times 3$ & 56 & 20 & $2 \cdot 16$ & - & $0 \cdot 01$ & $\begin{array}{r}900 \\
1000\end{array}$ & 100 & 低速 & $1 \cdot 8$ \\
\hline$o-5$ & $\begin{array}{l}\text { 外径 } 25, \text { 内径 } \\
4, \text { 厚さ3 }\end{array}$ & 63 & 20 & $2 \cdot 40$ & & - & $820 \sim 884$ & 50 & 30 & $0 \cdot 4$ \\
\hline
\end{tabular}

験片を浸漬するいわゆる溶洞塩淘布法とに分けられる. そしてこの両者の問には試験初期の腐食過程に差のある ことが報告されている10). 加速試験としてこのいずれの 方法が適当であるかという本質的問題は現在まだ明らか でないが; 後者の溶融塩塗衍法では溶融灰に浸漬したの ち余分の灰を削り取ろうとすると染布㬝全体がはく嚄し やすいため, 所定量の灰を叙有することの困難なことが 指摘された。それゆえ，主として技術的な面から混合壏
㳂布法を用いることとし，提案のあつたアセトンによる 方法と水ガラスによる方法とを後述の試験結果の図中に 記したように参加各機関で分担して行なうこととした. そしてアセトン法と水ガラス法の乎順をつぎのように定 めた.

i ) アセトン法

a) 所定混合比の合成灰を乳鉢でよくすりつぶしたの ち 2 〜 倍のアセトンを加える・b）よくかきまぜなが 


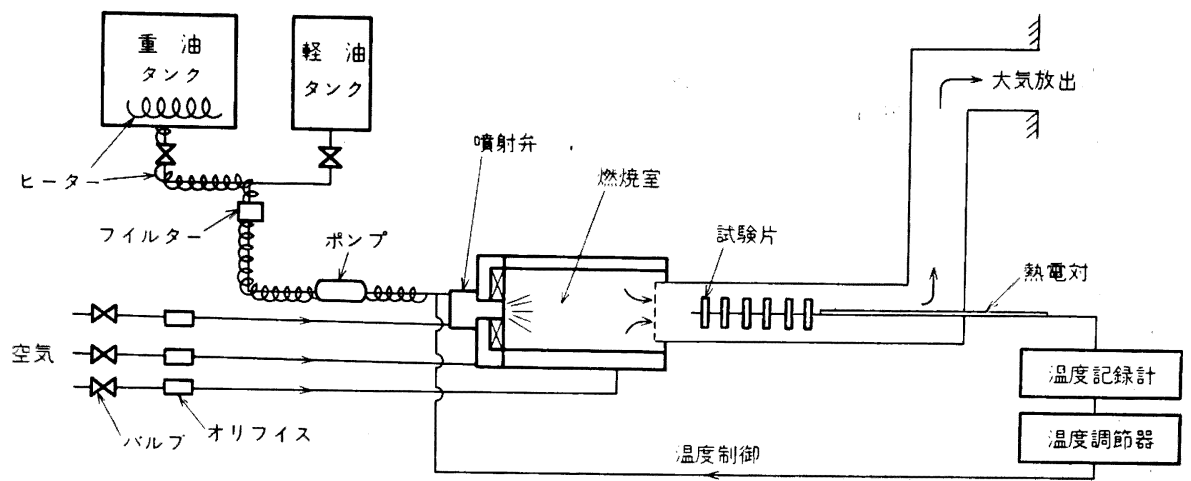

図 1 燃燒試験装置 $(\mathrm{O}-5)$

表 5 全浸漬および半浸漬試験の条件（昭和 45 年度）

\begin{tabular}{|c|c|c|c|c|c|c|c|c|c|}
\hline 試験 & $\begin{array}{c}\text { 試 験 片 } \\
\text { 形状寸法 } \\
(\mathrm{mm})\end{array}$ & 仕上方法 & $\begin{array}{l}\text { ルツボ } \\
\text { の材質 } \\
\text { と型 }\end{array}$ & $\begin{array}{l}1 \text { 個のルッボ } \\
\text { 中の合成灰の } \\
\text { 量, 溶融灰の } \\
\text { 深さ }\end{array}$ & $\begin{array}{l}\text { 試臨 } \\
\text { 片の } \\
\text { おき } \\
\text { 方 }\end{array}$ & $\begin{array}{l}1 \text { 個の } \\
\text { ルツボ } \\
\text { 中の試 } \\
\text { 験片数 }\end{array}$ & $\begin{array}{l}1 \text { 個の } \\
\text { 炉中の } \\
\text { ルツボ } \\
\text { 数 }\end{array}$ & 脱スケール法 & $\begin{array}{c}\text { 忓 の 型 } \\
\text { 内のり寸法 } \\
(\mathrm{mm})\end{array}$ \\
\hline$e-1$ & $12 \phi \times 12$ & $\begin{array}{l}\text { エメリー } \\
=500\end{array}$ & $\begin{array}{l}\mathrm{SSA}-\mathrm{H} \\
\mathrm{B}-2\end{array}$ & $\begin{array}{l}\text { 試験片上面よ } \\
\text { り約 } 5 \mathrm{~mm}\end{array}$ & $\begin{array}{l}\text { たて } \\
\text { おきき }\end{array}$ & 1 & $\begin{array}{l}9 \text { 市た } \\
\text { は } 6\end{array}$ & $\begin{array}{l}\mathrm{NaOH} 40 \%+\mathrm{Na}_{2} \\
\mathrm{CO}_{3} 60 \% \text { 電解 }\end{array}$ & $\begin{array}{l}\text { 橫型管状 } \\
160 \phi \times 1000\end{array}$ \\
\hline$f-2$ & " & 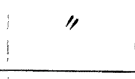 & " & 試験片の $1 / 4$ & " & 1 & 5 & " & $\begin{array}{l}\text { 箱型エレマ } \\
600 \times 800 \times 800\end{array}$ \\
\hline $\mathrm{j}-2$ & " & " & " & $\begin{array}{l}5 \mathrm{~g} \text {, 試験片 } \\
\text { の } 1 / 4\end{array}$ & " & 1 & 2 & " & $\begin{array}{l}\text { 二ク口公 } \\
\text { 横型管状 }\end{array}$ \\
\hline
\end{tabular}

ら，この䁘濁液を所定の量になるまで筆で何度も試験片 に塗る.

ii) 水ガラス法

a) 水ガラス（JIS 1 号）を 7 倍程度の水でうすめた 溶液中に試験片を浸し，表面が均一にぬれたら余分な液 はたらす、b ) 所定混合比の合成灰を乳鉢でよくすりつ ぶしたのち，紙の上にうすくひろげ，その上に試験片を 押しつけてやや多めに塗布する，c）要与れば $300^{\circ} \mathrm{C}$ 程度に加熱して乾燥させたのち余分な灰を静かにかき落 す.

塗布量も重要な試駼条件の1つである. 塗布量が少な いと試験結果のばらつきが多くなり,かつ試験中に腐食 作用が低下する．20〜 $500 \mathrm{mg} / \mathrm{cm}^{2}$ という比較的多い塗 布量の試験も行なわれているが10)，塗布量があまり多い と溶融灰が下へたれ落ちるとの意見もあつた．結局前年 度の共同研究における叙布量 $5 \sim 20 \mathrm{mg} / \mathrm{cm}^{2}$ を参考にし て一応 $20 \mathrm{mg} / \mathrm{cm}^{2}$ に統一した。

試験片の支持方法およびそのほかの条件はつぎのとお りに定めた：ｉ）試駼片はアルミナ燃焼ボート SSA-H の縁に亡たがせてのせる、ボートの大きさ，一度にのせ る試験片数はとくに规定しない，ii）所定温度になつて

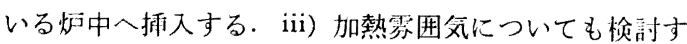
べき問題が多いと思われるが11)，今回は一応静止大気中 としたｉv）灯にはふた㐫る。

脱スケール法はなるべく $\mathrm{NaOH} 40 \%+\mathrm{Na}_{2} \mathrm{CO}_{3} 60 \%$ の溶融塩中での電解はく嚄上与る.

(3) 燃焼試験

燃烓試験は 45 年度は1機閉で行なわれた。その試験 条件を先の表 4 にあわせて示した．同機関に上つて前年 度行なわれた O-5 試験と異なるおもな点は, 前年度は A 重油に $\mathrm{V}_{2} \mathrm{O}_{5}$ と $\mathrm{Na}_{2} \mathrm{SO}_{4}$ を加えたものを燃料とした が，今回は表示のような組成の $\mathrm{C}$ 重油を用いたことであ る。

（4）酸素消費量試験

この試験は燃烸灰中の $\mathrm{V}_{2} \mathrm{O}_{5} や ，$ 低融点高尞父圧の $\mathrm{M}_{0} \mathrm{O}_{3}, \mathrm{WO}_{3}$ 泳どの酸化物による加速酸化はいずも反応 過程に酸素が関与与ることに注目し，腐食反応中に消費 された酸素量から試験片の腐食度を評洒するものであ る. 2 機関で行なわれた試駼の試験条件を表 6 に示す. 試験装置は j-6 ではBRASUNAS ら ${ }^{12)}$ の用いたものとほぼ 同様のものを組み立てて使用した， m-6では図 2 に示 すような谷量の大きい装置を組み立てた、試験片をおさ める炉心管は内径 $80 \mathrm{~mm}$, 長さ $1 \mathrm{~m}$ の不透明石英管で, 酸素消費量測定用のビューレット管は内径約 $40 \mathrm{~mm}$ の ものを図のように 4 本证列にならべた，図の左側の水槽 はこれを上下して外王との平衡関係を用いて酸素消費量 
表 6 酸 素 消 費 量 試 験 の 条 件(昭和 45 年度)

\begin{tabular}{|c|c|c|c|c|c|c|c|}
\hline 試験 & $\begin{array}{l}\text { 試験片形 } \\
\text { 状寸法 } \\
(\mathrm{mm})\end{array}$ & 仕上方法 & $\begin{array}{l}\text { 合成灰 }\left(85 \% \mathrm{~V}_{2} \mathrm{O}_{5}\right. \\
\left.+15 \% \mathrm{Na}_{2} \mathrm{SO}_{4}\right) \\
\text { の塗布方法 }\end{array}$ & $\begin{array}{c}\text { 塗布量 } \\
(\mathrm{mg} / \\
\left.\mathrm{cm}^{2}\right)\end{array}$ & $\begin{array}{l}\text { 試 験片 の } \\
\text { 支持方法 }\end{array}$ & 脱スケール法 & $\begin{array}{l}\text { 炉の型, 内のり寸 } \\
\text { 法 (mm) } \\
\text { 炉心管内径 }(\mathrm{mm})\end{array}$ \\
\hline $\mathrm{j}-6$ & $12 \phi \times 12$ & $\begin{array}{l}\text { エメリー } \\
\# 500\end{array}$ & $\begin{array}{l}\text { クリヤラッカーを } \\
\text { うすく吹きつけ全 } \\
\text { 面に均一散布 }\end{array}$ & 20 & 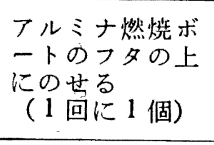 & $\begin{array}{l}\mathrm{NaOH} 40 \%+ \\
\mathrm{Na}_{2} \mathrm{CO}_{3} 60 \% \\
\text { 電解 }\end{array}$ & $\begin{array}{c}\text { 横型管状师 } \\
30\end{array}$ \\
\hline$m-6$ & $15 \phi \times 3$ & $\begin{array}{l}\text { エメリー } \\
\$ 03\end{array}$ & アセトン法による & " & $\begin{array}{l}\mathrm{SSA}-\mathrm{H} \quad \mathrm{B}-2 \\
\text { ルツボ中へおさ } \\
\text { める }\end{array}$ & " & $\begin{array}{c}\text { 横型管状炉 } \\
110 \phi \times 500 \\
80\end{array}$ \\
\hline
\end{tabular}

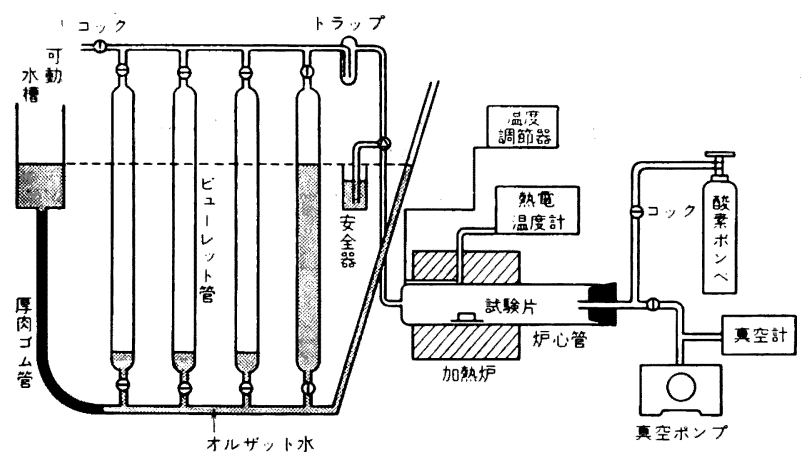

図 2 酸素消費量測定装置 $(m-6)$

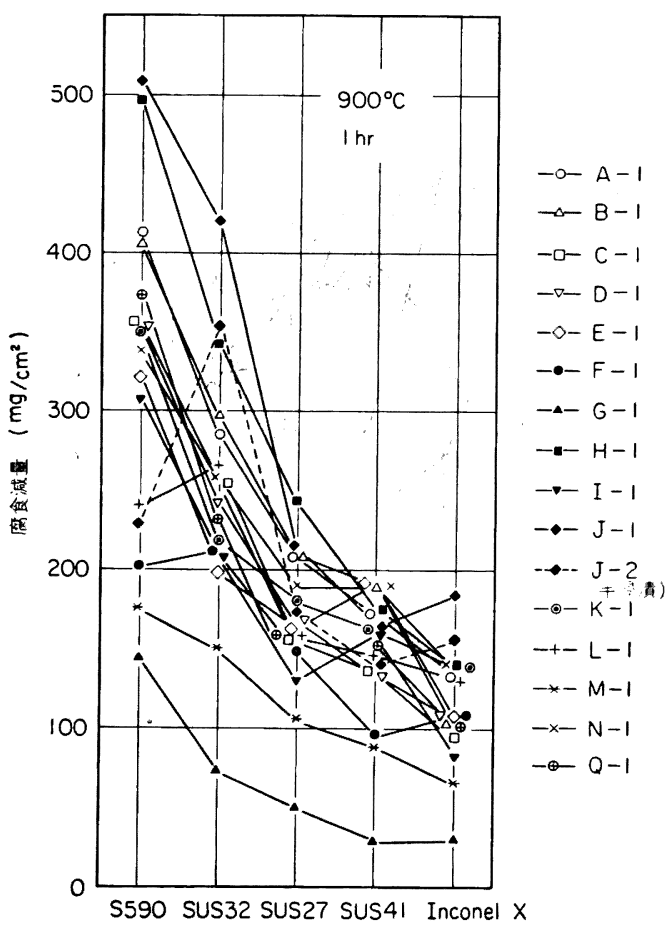

図 $3900^{\circ} \mathrm{C}-1 \mathrm{hr}$ 全浸漬および半浸漬（J-2）試騟結果
を測定するためのものである.

\section{3. 試 験 結 果}

\section{1 昭和 44 年度の試験結果}

$3 \cdot 1 \cdot 1$ 全浸漬および半浸漬試験

(1) 各供試材の腐食減量

図 3 に各機関の $900^{\circ} \mathrm{C}-1 \mathrm{hr}$ の全浸漬打よ び半浸漬 (J-2) 試験の結果をとりまとめて 示した. 各機関とも同一条件で 3 個のデー夕 をとつており，図示された実験点はそれらの 平均値である. 以下に述べる試験において も，燃燒試験を除いてすべて同様である.同 図をみると，共通の供試材を用い試験温度と 時間, 合成灰の組成を統一したにもかかわらず, 腐食隇 量の絶対値には各機関の間に大きなひらきがある.しか 乙各供試材の腐食減量をみると，大体の傾向は S 590 が 最も多く, SUS 32, SUS 27, SUS 41, Inconel X の順 に少なくなつている.図 4 は腐食減量の絶対値はさてお き, 各機関ごとに全供試材の腐食隇量の和を 100 とし, 各供試材の腐食隇量がそれぞれその和の何\%に当たるか を図示したものである：これをみると多少の変動はある が上記の順位がさらにはつきり認められる.

図 5 は全浸漬試験における腐食減量の全機関にわたつ ての平均值を示したものである。また図 6 は各機関のデ 一夕において腐食減量の最大の供試材に 5 , 第 2 第 5 位のあのにそれぞれ 4〜1をあたえて，それらの数をそ れぞれ各供試材ごとに平均した值を示したものである. これらの平均值が $5 \sim 1$ の数のいずれかにそれぞれ近い ほど，各供試材の腐食減量の順位は各機関を通じてょく 揃つていることを示す. 図 5 および図 6 からも $900^{\circ} \mathrm{C}-$ $1 \mathrm{hr}$ の全浸漬試験では腐食減量に関する上記の順位が全 機関を通じて非常によく揃つていることがわかる.

つぎに $800^{\circ} \mathrm{C}-20 \mathrm{hr}$ の試験結果について述べる. 図 7 は $800^{\circ} \mathrm{C}-20 \mathrm{hr}$ の全浸漬および半浸漬 $(\mathrm{J}-2)$ 試験の結 果を示す. これをみると, $800^{\circ} \mathrm{C}-20 \mathrm{hr}$ の場合も腐食減 量そのものが各機関の間で大きな差がある.しかも腐食 隇量の順位は $900^{\circ} \mathrm{C}$ の場合のように各機関を通じて揃 つていない。このことは全供試材の腐食減量の和に対す 


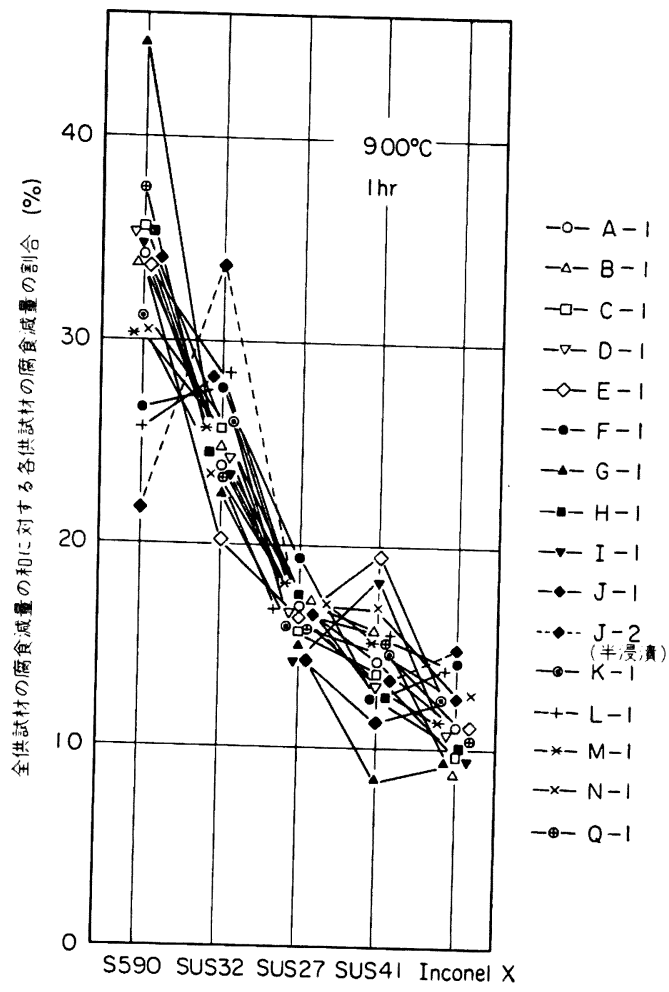

図 4 全供試材の腐食減量の和に対する各供試材の 腐食減量の割合

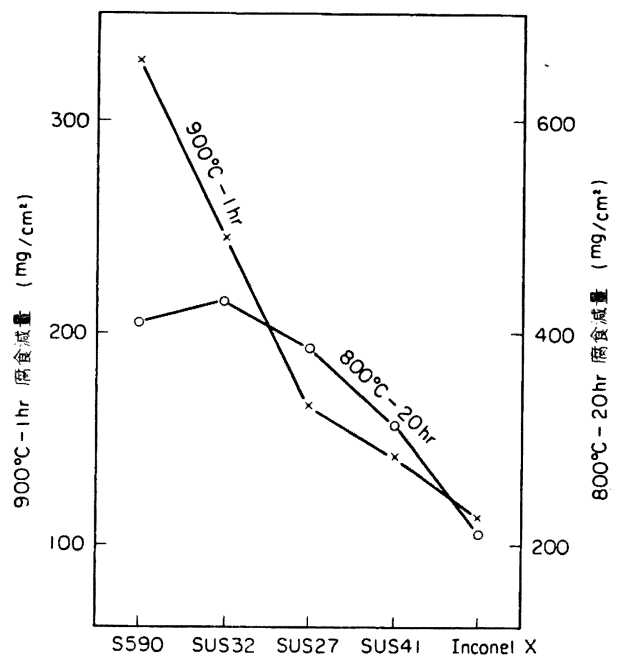

图 5 全浸溑試験における腐食減量平均値

る各供試材の腐食減量の敖合を示した闵 8 をみてもよく わかる.そこで $900^{\circ} \mathrm{C}$ の場合と同様に腐食減量の平均 倠を各供試材について求めて図 5 にのせた。腐食減量の 平均值では 1 位と 2 位が $900^{\circ} \mathrm{C}$ の場合に比べて逆転し

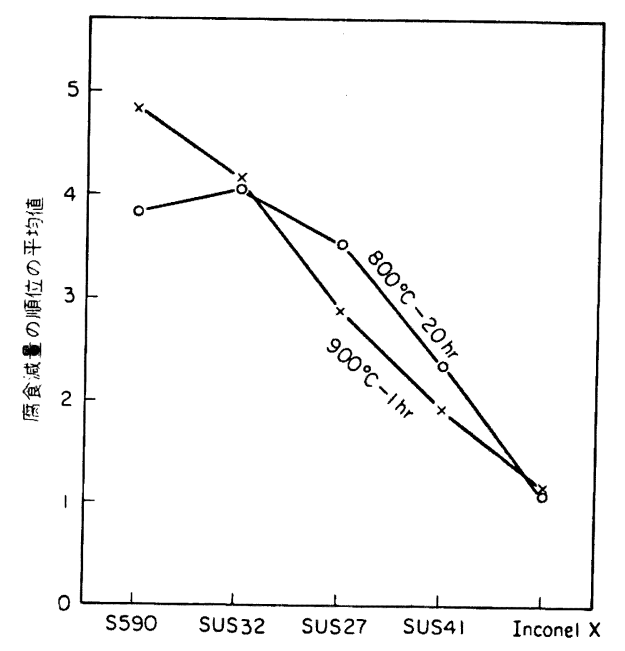

因 6 全浸清試験における腐食減量の順位の平均值

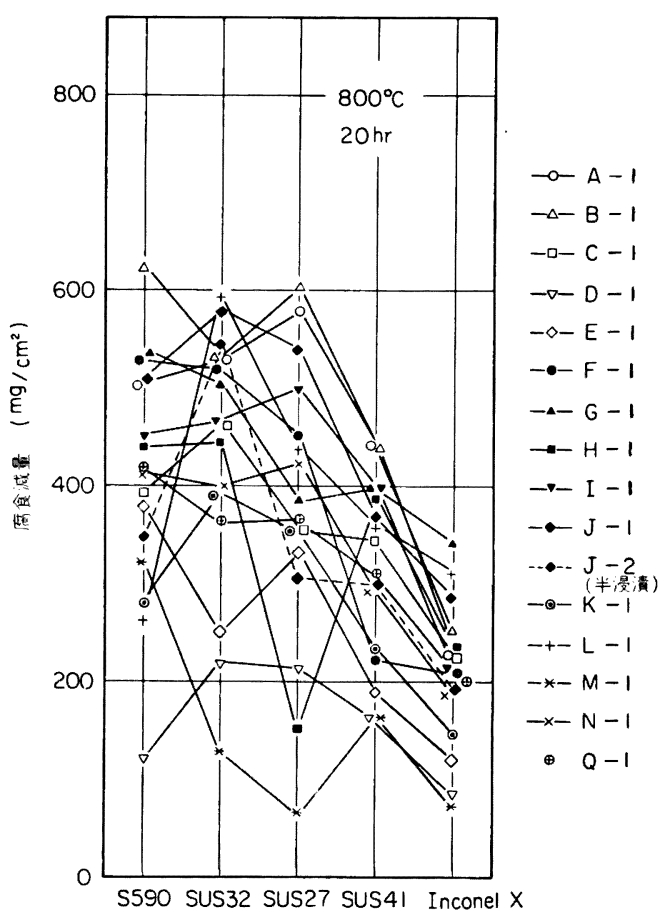

図 $7800^{\circ} \mathrm{C}-20 \mathrm{hr}$ 全浸漬および半浸漬 $(\mathrm{J}-2)$ 試験結果

ており, しかも $1 〜 3$ 位の間の差が少ない.さらに腐食 減量の順位を $1 \sim 5$ の数を用いて前述のように求めてみ ると, 図 6 に示したように平均值とよく似た傾向を示 し， 1 〜 位の供試材の順位がとくに不揃いである. 以 上のように $900^{\circ} \mathrm{C}-1 \mathrm{hr}$ と $800^{\circ} \mathrm{C}-20 \mathrm{hr}$ の試験結果は かなり巽なつた傾向を示すが，その理由については現在 まだ明らかでない。 


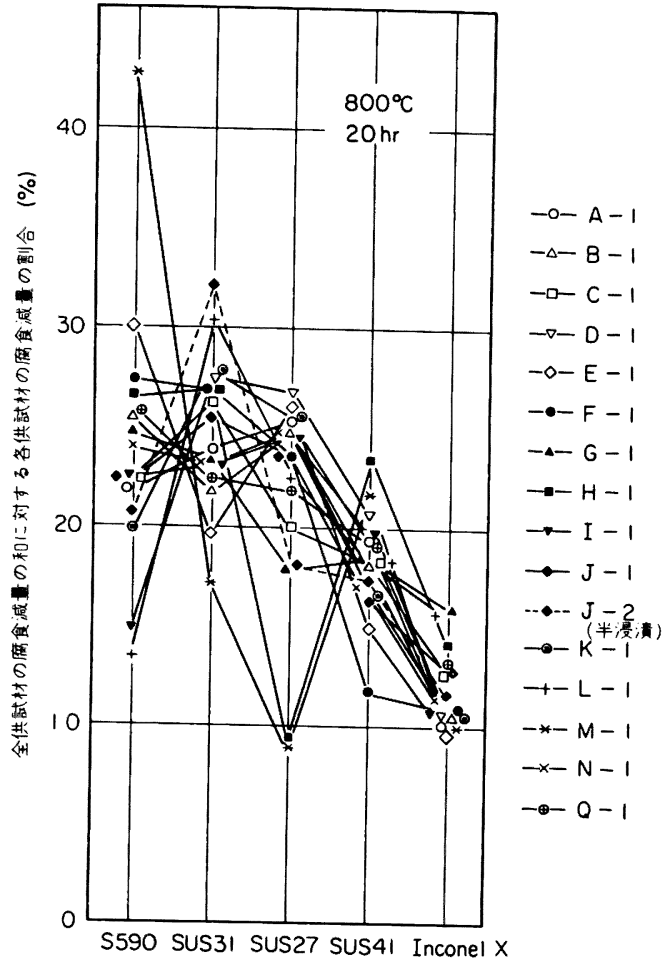

因 8 全供試材の腐食減量の和に対する各供試材の 腐食減量の割合

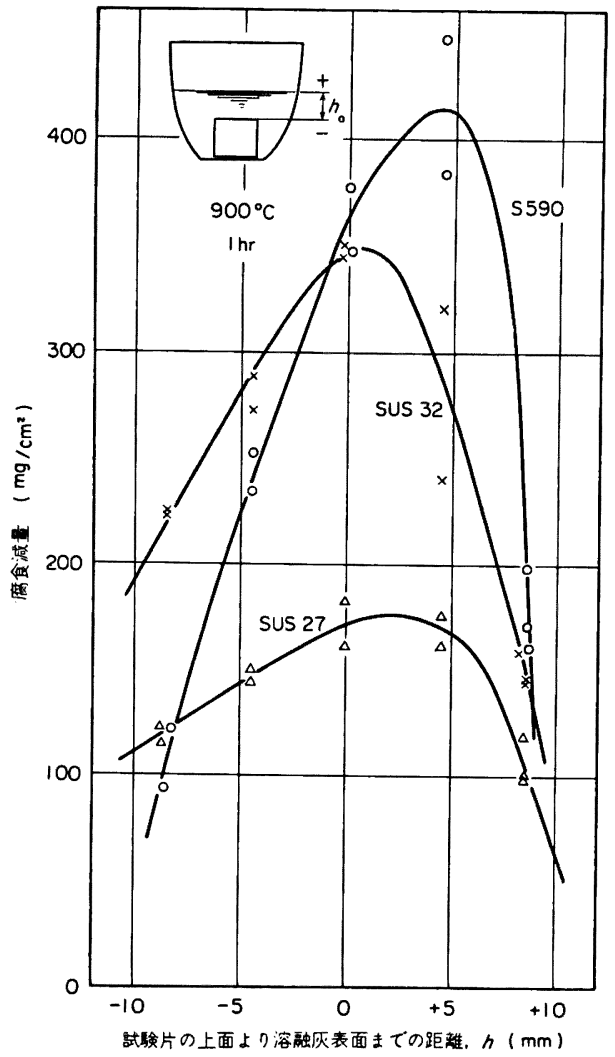

図 9 浸漬試験における腐食減量一の合成灰の量の影留

表 7 腐食減量への合成灰組成の影響（全浸清試験）

\begin{tabular}{|c|c|c|c|c|c|c|}
\hline & \multicolumn{3}{|c|}{$900^{\circ} \mathrm{C}-1 \mathrm{hr}$} & \multicolumn{3}{|c|}{$800^{\circ} \mathrm{C}-20 \mathrm{hr}$} \\
\hline & $\begin{array}{c}15 \% \text { の } \mathrm{Na}_{2} \mathrm{SO}_{4} \text { 加え } \\
\text { たときの腐食隇量 } \mathrm{A} \\
\left(\mathrm{mg} / \mathrm{cm}^{2}\right)\end{array}$ & $\begin{array}{l}\mathrm{V}_{2} \mathrm{O}_{5} \text { のみのと } \\
\text { きの噟食隇量 } \mathrm{B} \\
\left(\mathrm{mg} / \mathrm{cm}^{2}\right)\end{array}$ & $\mathrm{A} / \mathrm{B}$ & $\begin{array}{c}15 \% \text { の } \mathrm{Na}_{2} \mathrm{SO}_{4} \text { 加え } \\
\text { たときの腐食隇量 } \mathrm{A} \\
\left(\mathrm{mg} / \mathrm{cm}^{2}\right)\end{array}$ & $\begin{array}{l}\mathrm{V}_{2} \mathrm{O}_{5} \text { の多のと } \\
\text { きの腐食減量 } \mathrm{B} \\
\left(\mathrm{mg} / \mathrm{cm}^{2}\right)\end{array}$ & $\mathrm{A} / \mathrm{B}$ \\
\hline $\begin{array}{l}\text { S } 509 \\
\text { SUS } 32 \\
\text { SUS } 27 \\
\text { SUS } 41 \\
\text { Inconel } \mathrm{x}\end{array}$ & $\begin{array}{r}144 \\
72 \\
49 \\
27 \\
30\end{array}$ & $\begin{array}{r}101 \\
47 \\
24 \\
48 \\
28\end{array}$ & $\begin{array}{l}1 \cdot 43 \\
1 \cdot 53 \\
2 \cdot 04 \\
0 \cdot 56 \\
1 \cdot 07\end{array}$ & $\begin{array}{l}524 \\
504 \\
386 \\
397 \\
342\end{array}$ & $\begin{array}{r}198 \\
43 \\
31 \\
9 \\
58\end{array}$ & $\begin{array}{l}2 \cdot 65 \\
11 \cdot 7 \\
12 \cdot 4 \\
12 \cdot 8 \\
5 \cdot 90\end{array}$ \\
\hline
\end{tabular}

（2）腐食減量に対する各種因子の影響

G-1 試験では合成灰として $\mathrm{V}_{2} \mathrm{O}_{5}$ のみを用いた試験 も行なつている. そして $15 \%$ の $\mathrm{Na}_{2} \mathrm{SO}_{4}$ を加えた場合 と $\mathrm{V}_{2} \mathrm{O}_{5}$ のみの場合の腐食減量を比べると表 7 のように なる. $\mathrm{Na}_{2} \mathrm{SO}_{4}$ を加えると腐食減量は一般に增大寸るが, その影響は $800^{\circ} \mathrm{C}-20 \mathrm{hr}$ 試験のほうが $900^{\circ} \mathrm{C}-1 \mathrm{hr}$ 試験 よりはるかに著しい。

つぎに合成灰の量の影響について述べる. 1 個のルッ ボ中の合成灰の量を $10 \mathrm{~g}$ とした J-2 の半浸漬試験結果 をたとえば図 3 や図 4 にみると，眓中破線で示すように S 590 と SUS 32 の腐食減量の関係が全浸漬試験の場合
と大きく逆転していることが注目される．また同じ全浸 漬試験でも表 2 に示したように灰の量は $30 \sim 80 \mathrm{~g}$ の範 囲でかなりまちまちであり，このようなことが上述のよ うに腐食減量のひらく原因となりかねない，そこで $\mathrm{S}$ 590, SUS 32, SUS 27 の 3 供試材について灰の量だけ を大幅に変えて $900^{\circ} \mathrm{C}-1 \mathrm{hr}$ の浸漬試験を行なつた. 図 9 はその結果で, 図中横軸の $h=0$ は溶融灰の表面と試 験片の上面とがほぼ同一レベルに市場合を指す。した がつて. これより右側は全浸漬試験, 左側は半浸漬試験 となる.この四をみると各供試材の腐食減量は浸漬深さ $h$ の大小によつて著しく影響されることが明らかであ 
る. 各供試材とも $h=0 \sim 5 \mathrm{~mm}$ のところに腐食溶量の ピークを生じ，そのピークの大きさは供試材によつてそ れぞれ異なる. $h>0$ の全浸漬試験についていえば，浸 漬深さが增していくと腐食隇量は急激に減少するが，こ れは試験後の試験片の噟食状況などからみて主として雾 囲気からの酸素供給量の多少による影響と考えられる. つぎに S 590 と SUS 32 の腐食減量を比べてみると, おおよそ $h=0$ を境として，その右側では S 590 のほう が隇量が多く,また左側では SUS 32 のほうが腐食が著 しい.この結果は $900^{\circ} \mathrm{C}-1 \mathrm{hr}$ の全浸漬試験では一般に S 590 のほうが減量が多く, 半浸漬試験（J-2）では逆 にSUS 32 のほうが減量が多いという前述の試験結果と よく一致する.

腐食減量に対する合成灰の 銘柄(6)やルツボ材質22,6) の影響，また試験を連続的に行なわず，たとえば $20 \mathrm{hr}$ の試験を $5 \mathrm{hr}$ ずつ 4 回繰り返した場合の影響2などに ついても検討されているが，紙面の関係で省略する.

\section{$3 \cdot 1 \cdot 2$ 塗布試験}

(1) 各供試材の腐食減量

図 10 および図 11 に試験結果をとりまとめて示す.こ れらの図からわかるように，塗布試験結果は全浸漬試験 結果と全く趣を異にし，各試験温度の場合とも腐食減量 はSUS 32 が群を妨いて多く, ついで SUS 27, SUS 41, S 590, Inconel X という順位が大勢を占的ている。 そ して全浸漬試験で非常に腐食されやすかつた S 590 が染

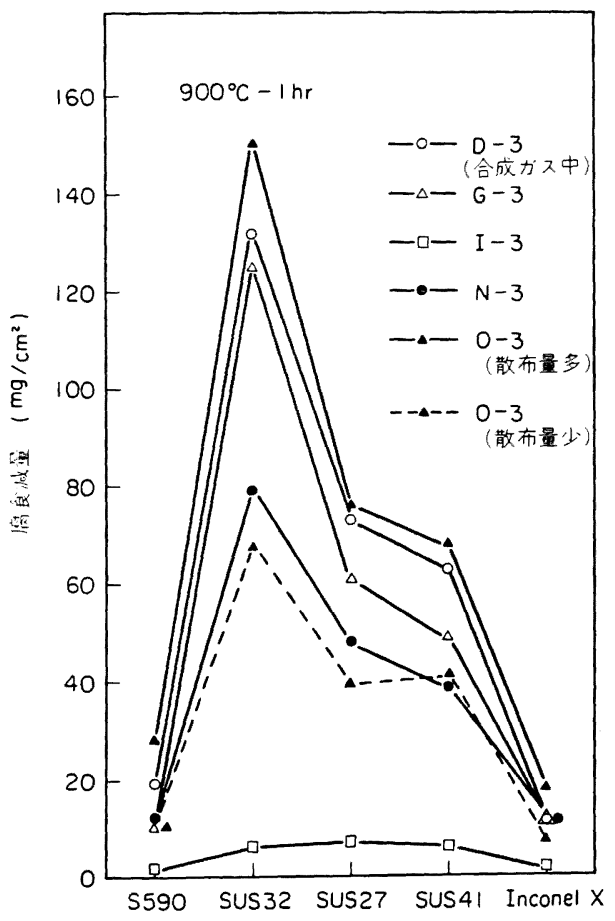

図10 $900^{\circ} \mathrm{C}-1 \mathrm{hr}$ 叙布試験結果

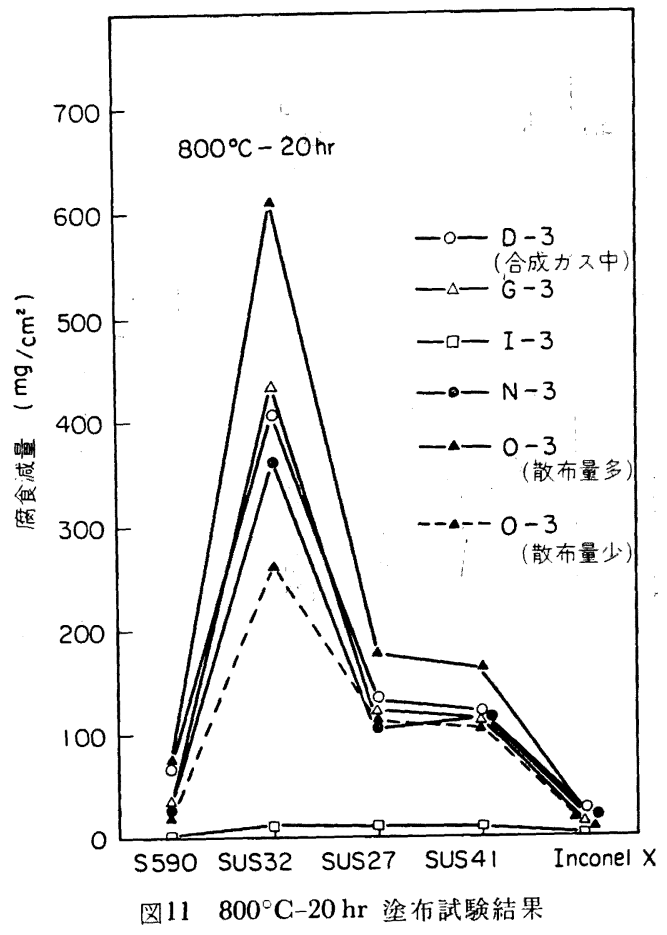

布試験では Inconel X に近い非常に少ない腐食減量を 示寸.このような腐食減量の傾向は各供試材の腐食減量 の平均值を示した図 12 をみてもよくわかる.また塗布 試験では SU S27 とSUS 41 の間では腐食減量にあまり 大きな差は羿められない。

（2）腐食減量に対する各種因子の影響

G-3 試験では全浸漬試験の場合と同様に, 合成灰とし て $\mathrm{V}_{2} \mathrm{O}_{5}$ のみを用いた場合の試験も行なつている. $15 \%$ の $\mathrm{Na}_{2} \mathrm{SO}_{4}$ を添加したことによる影響を表 8 にると， 腐食の促進される程度はやはり $800^{\circ} \mathrm{C}-20 \mathrm{hr}$ 試験のほ うが概して著しい。 また $\mathrm{Na}_{2} \mathrm{SO}_{4}$ を添加したための影 響は S 590 ではほかの供試材に比べて逆の結果になつて

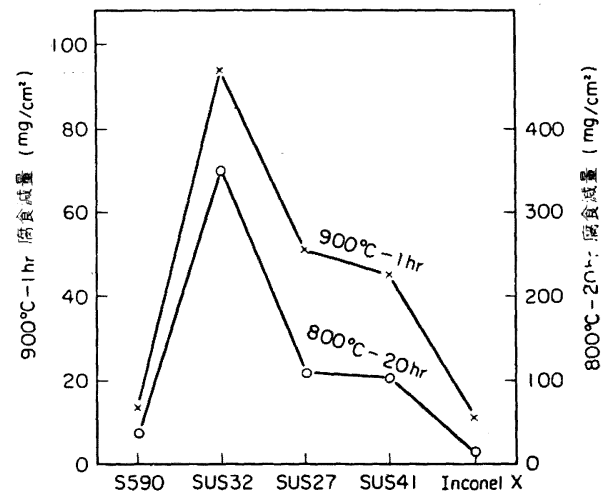

図12 塗布試験における腐食減量平均值 
表 8 腐食減量一の合成灰組成の影響（涾布試験）

\begin{tabular}{|c|c|c|c|c|c|c|}
\hline & \multicolumn{3}{|c|}{$900^{\circ} \mathrm{C}-1 \mathrm{hr}$} & \multicolumn{3}{|c|}{$800^{\circ} \mathrm{C}-20 \mathrm{hr}$} \\
\hline & $\begin{array}{l}15 \% \text { Na } \mathrm{SO}_{4} \text { を } \\
\text { 加えたときの糜食 } \\
\text { 減量 } \mathrm{A}\left(\mathrm{mg} / \mathrm{cm}^{2}\right)\end{array}$ & $\begin{array}{r}\mathrm{V}_{2} \mathrm{O}_{5} \text { のみのとき } \\
\text { の腐食減量 } \mathrm{B} \\
\left(\mathrm{mg} / \mathrm{cm}^{2}\right)\end{array}$ & $\mathrm{A} / \mathrm{B}$ & $\begin{array}{l}15 \% の \mathrm{Na}_{2} \mathrm{SO}_{4} \text { を } \\
\text { 加えたときの腐食 } \\
\text { 減量 } \mathrm{A}\left(\mathrm{mg} / \mathrm{cm}^{2}\right)\end{array}$ & $\begin{array}{r}\mathrm{V}_{2} \mathrm{O}_{5} \text { のみのとき } \\
\text { の腐食減量 } \\
\left(\mathrm{mg} / \mathrm{cm}^{2}\right)\end{array}$ & $\mathrm{A} / \mathrm{B}$ \\
\hline S 590 & 10 & 23 & $0 \cdot 44$ & 35 & 36 & 0.97 \\
\hline SUS 32 & 125 & 75 & $1 \cdot 67$ & 434 & 140 & $3 \cdot 10$ \\
\hline SUS 27 & 61 & 56 & $1 \cdot 09$ & 120 & 48 & $2 \cdot 50$ \\
\hline SUS 41 & 49 & 44 & $1 \cdot 09$ & 115 & 21 & $5 \cdot 48$ \\
\hline Inconel $\mathrm{X}$ & 11 & 5 & $2 \cdot 20$ & 14 & 7 & $2 \cdot 00$ \\
\hline
\end{tabular}

いる.

腐食減量に対しては塗布量の影響や前述のような断続 試験の影響も調べられている2)がここでは省略する。

\section{$3 \cdot 1 \cdot 3$ 交互浸漬試験}

交互浸漬試験 H-4 および J-4 の結果を図 13 に示す. $15 \mathrm{~min}$ 間ずつ浸漬と加熱を繰り返した $\mathrm{H}-4$ 試験では, $900^{\circ} \mathrm{C}-1 \mathrm{hr}$ の場合 S 590 の腐食減量が相対的に多く, 腐食減量の順位はむしろ全浸漬試験に近い. $800^{\circ} \mathrm{C}-8 \mathrm{hr}$ 試験では S 590 の腐食減量は SUS 32 より少ないが，塗 布試験の場合に比べると多めである.このようにいずれ の温度でも S 590 の腐食減量が塗布試験に比べて多めな のは，この試験が全浸漬試験と塗布試験の中間的性格を もつためと考えられる.つぎ J-4 試験 $\left(900^{\circ} \mathrm{C}-1 \mathrm{hr}\right)$ では腐食減量の順位は塗布試験に似ているが，やはり $\mathrm{S}$ 590 の腐食減量が相対的に多めである.

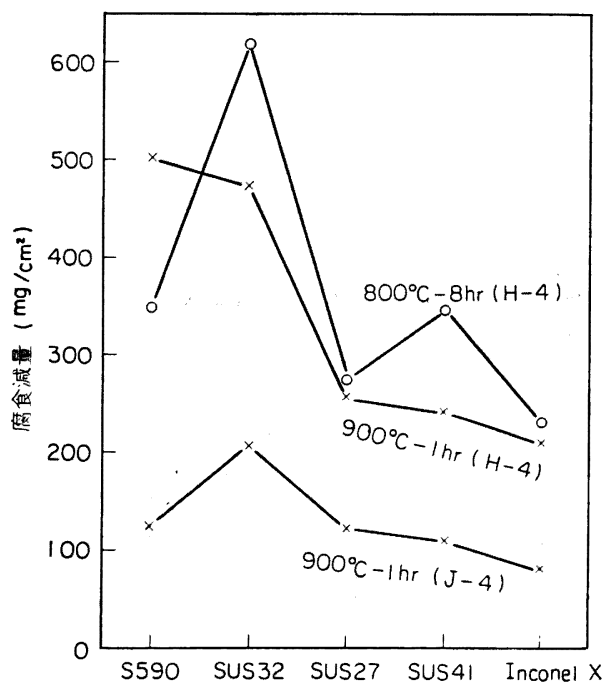

図13 交互浸漬試験結果 (H-4, J-4)

\section{$3 \cdot 1.4$ 燃燒試験}

燃焼試騟結果のおもなものを図 14〜図 18 に示す. ま ず G-5 試験（図 14）とK-5 試験（図 15）を比べると， 試験温度はほぼ同範囲，試験時間は同じ $100 \mathrm{hr}$ である が，後者のほうが全般に腐食減量が多い。これはガス流

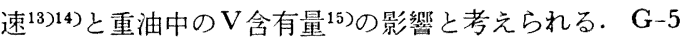
試験における腐食減量をみると, 平均值では塗布試験と 同样に SUS 32, SU S27, SUS 41, S 590, Inconel X の順に少なくなつている. しかし試験温度の低いほど $\mathrm{S}$ 590 の腐食減量が相対的に多めになり，上記の順位はく ずれる. 一方 K-5 試験では全温度を通じて上記の順位 となつている. またこの試験では S 590 は Inconel X とあまり変わらない良好な耐食性を示す.

つぎに O-5 試験の結果（図 16）をみると，この試験 は重油組成や試験温度, 時間が上記の 2 試験と異なるた

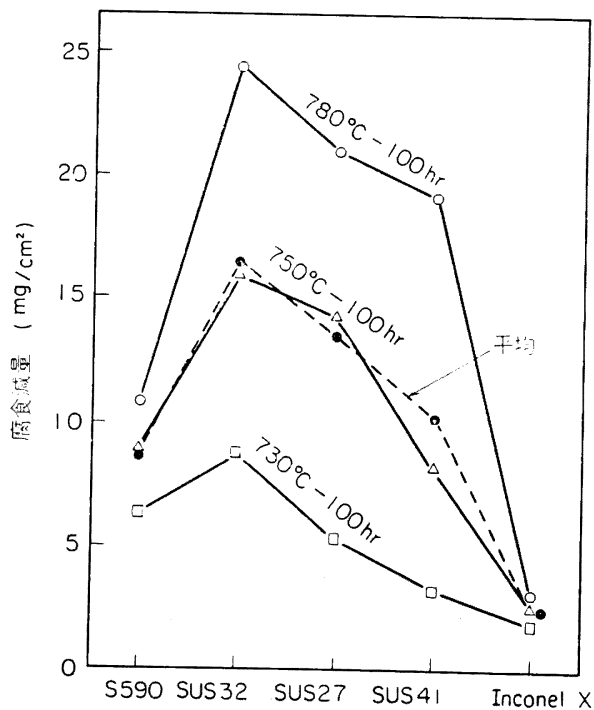

図14 燃焼試験結果 $(G-5)$ 

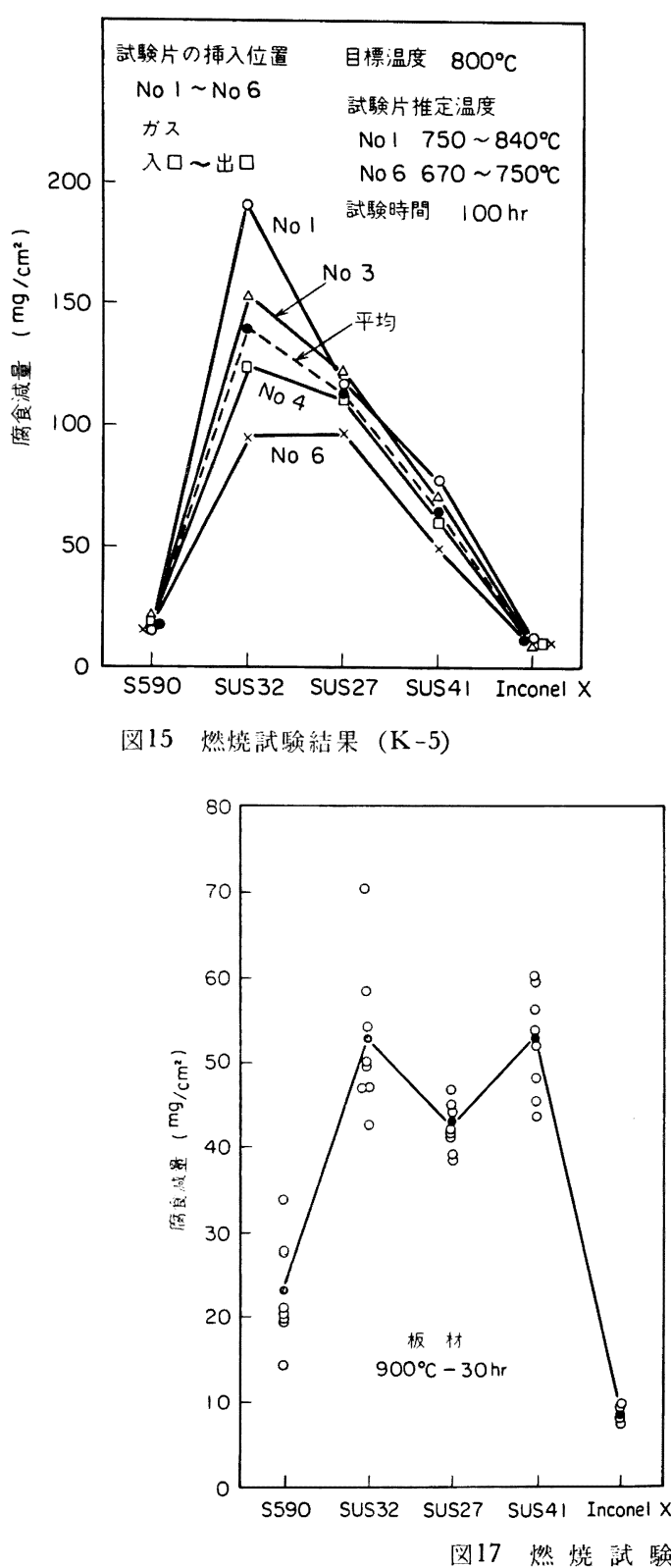
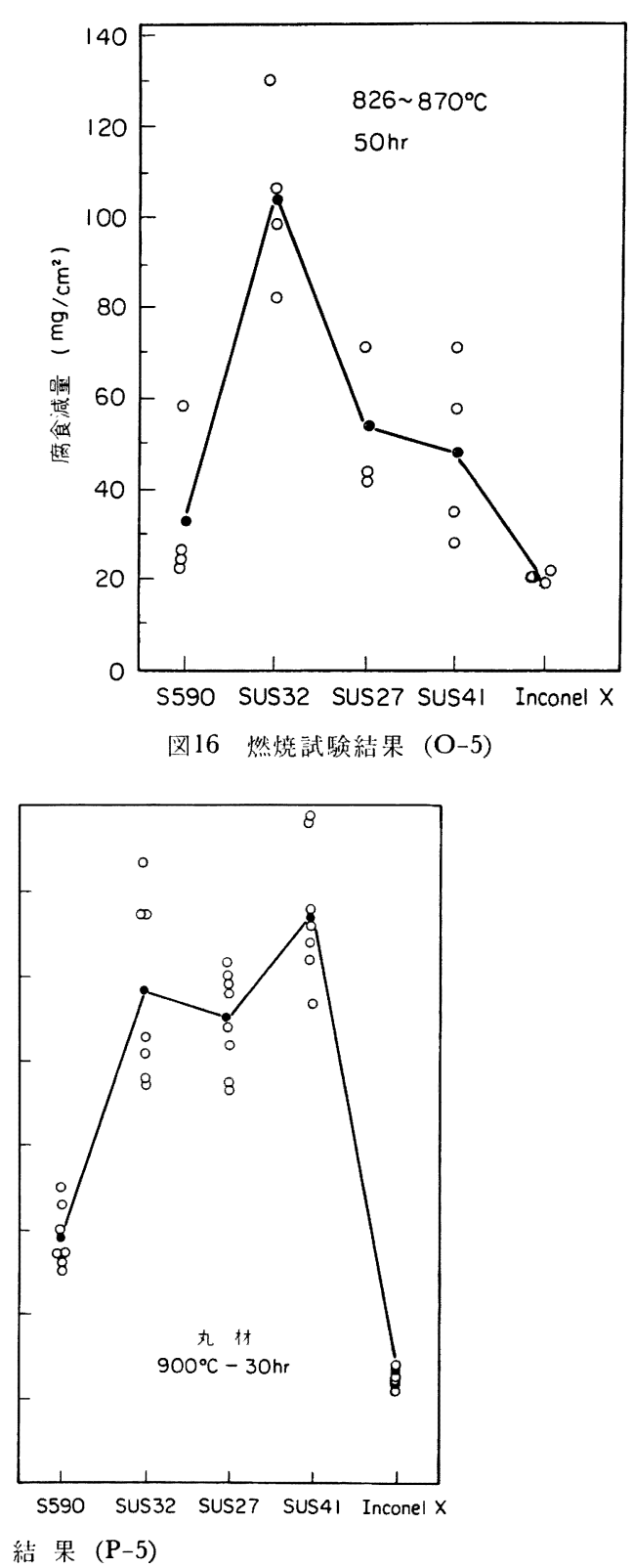

上著しく異なつている.またこのような傾向に関しては 再試䮖を行なつてこれを確認している.

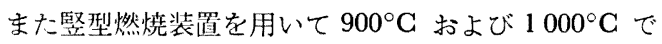
行なつた Q-5 試験（図 18）ではガス流速が低いため腐 食減量は全般的に少なく, $900^{\circ} \mathrm{C}, 1000^{\circ} \mathrm{C}$ とも $\mathrm{P}-5$ 試 験とは対照的に SUS 41 の腐食減量が最も少なく Inconel X よりさらに少なくなつている. また $900^{\circ} \mathrm{C}$ 試 験で SUS 27 が全供試材中最高の腐食量を示すことも特 徵的である.この試験では試験片にあらかじめ約 $70 \mathrm{mg} /$ 


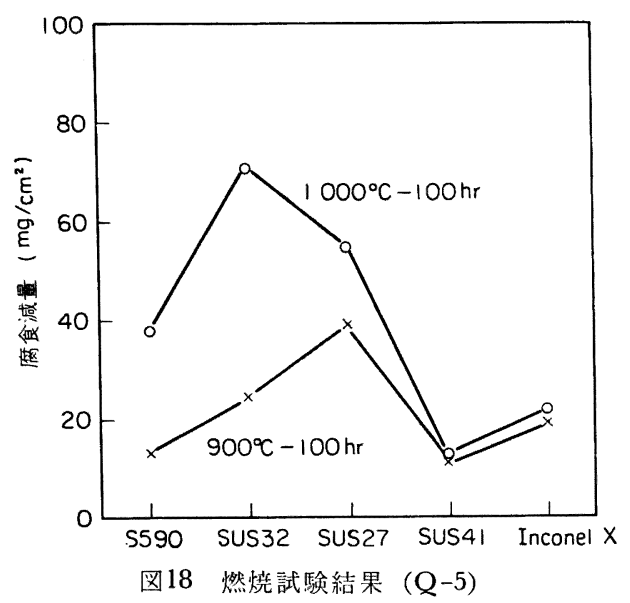

$\mathrm{cm}^{2}$ の $\mathrm{V}_{2} \mathrm{O}_{5}$ を塗布した場合についても試験 $\left(1000^{\circ} \mathrm{C}-\right.$ $100 \mathrm{hr})$ しているが, このようにすると腐食減量は著し く増大する.

\section{2 昭和 45 年度の試験結果}

$3 \cdot 2 \cdot 1$ 全浸漬および半浸漬試験

全浸漬試験 e-1 の結果を同機関によつて前年度行な

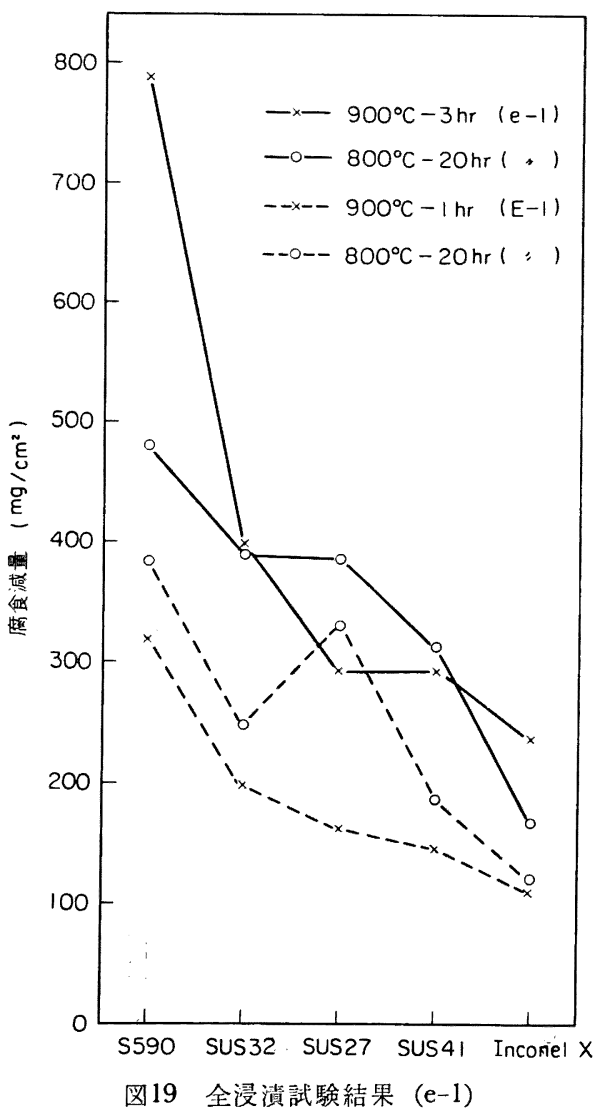

われた E-1 の結果と対比して図 19 に示す. まず 45 年 度の結果 (実線)についてみると，應食減量はいずれの 温度でもS 590 が最も多く，ついでほぼ SUS 32，SUS 27, SUS 41, Inconel X の順になつている. この傾向 は $900^{\circ} \mathrm{C}$ では前年度の試験絬果の一般的傾向と合致し， $800^{\circ} \mathrm{C}$ ではやや異なつている。しかしながら 45 年度は 件数が 1 件のみであるので，試験条件を統一したことに よる新知見はえられていないなお e-1 と E-1 とを比 ベてみると，同じ $800^{\circ} \mathrm{C}-20 \mathrm{hr}$ の場合，前者のほうが 腐食減量が全般的に多いが，これは主として浸漬深さ (e-1 では約 $5 \mathrm{~mm}$, E-1 では約 $15 \mathrm{~mm}$ ) の影響と考え られる。

つぎに半浸漬試験 $\mathrm{f}-2$ および $\mathrm{j}-2$ の結果を図 20 に 示した. S 590 とSUS 32 の腐食減量の相対的関係が 全浸漬試験の場合と全く逆になつていることがまず注目 される，腐食減量はいずれの試験でもSUS 32 がとび收 けて多く，ついで S 590 を除けば SUS 27, SUS 41,

Inconel X の順となつている. S 590 の腐食減量のほか の供試材に対する相対的比率は試験法が異なればもちろ え变わるが，同じ半浸漬試験でも $900^{\circ} \mathrm{C}-3 \mathrm{hr}$ の場合と $800^{\circ} \mathrm{C}-20 \mathrm{hr}$ の場合では異なるようである.

\section{$3 \cdot 2 \cdot 2$ 塗布試験}

(1) 各供試材の榢食減量

図 21 および図 22 にアセトン汒，図 23 および図 24

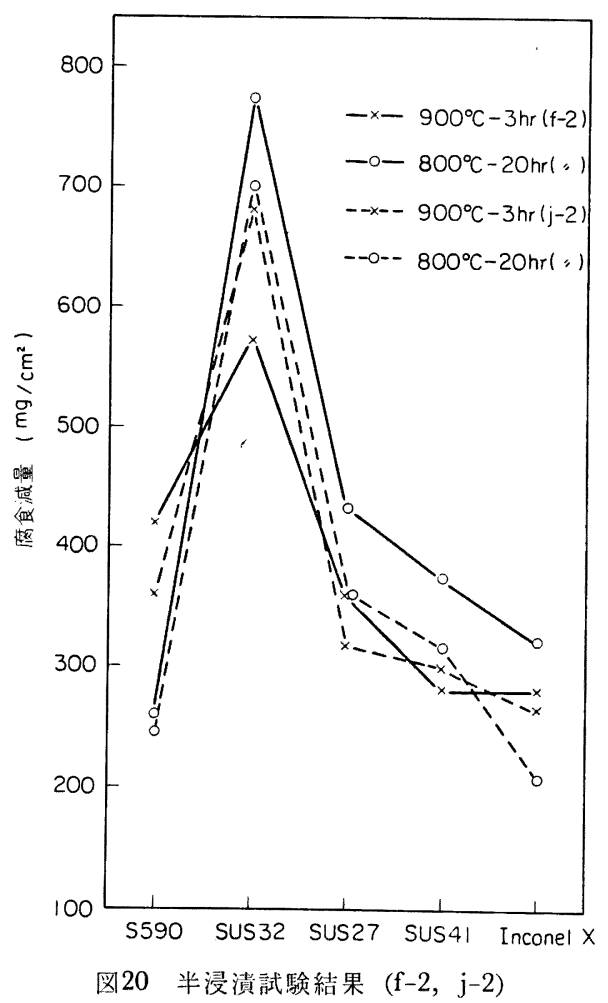



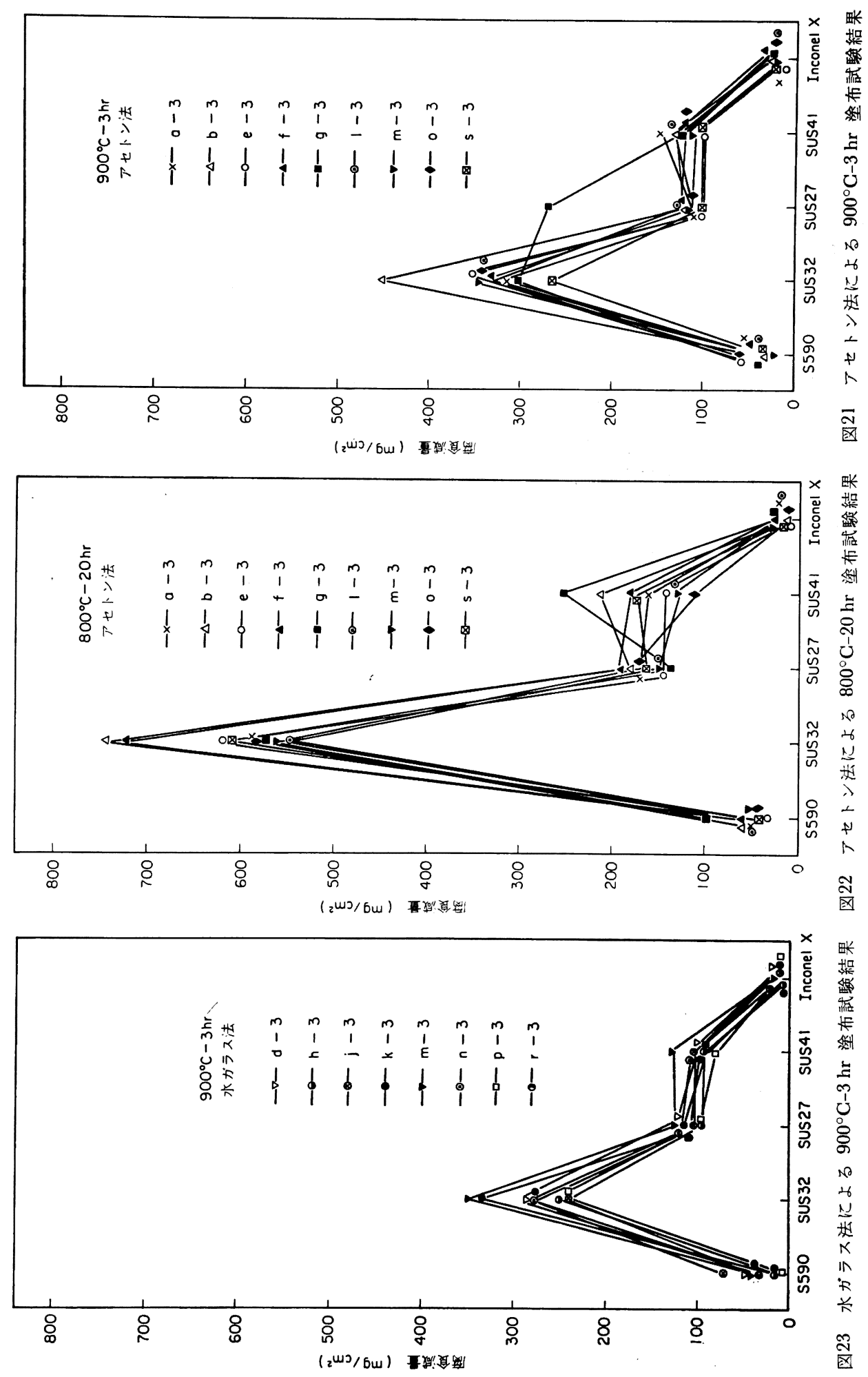

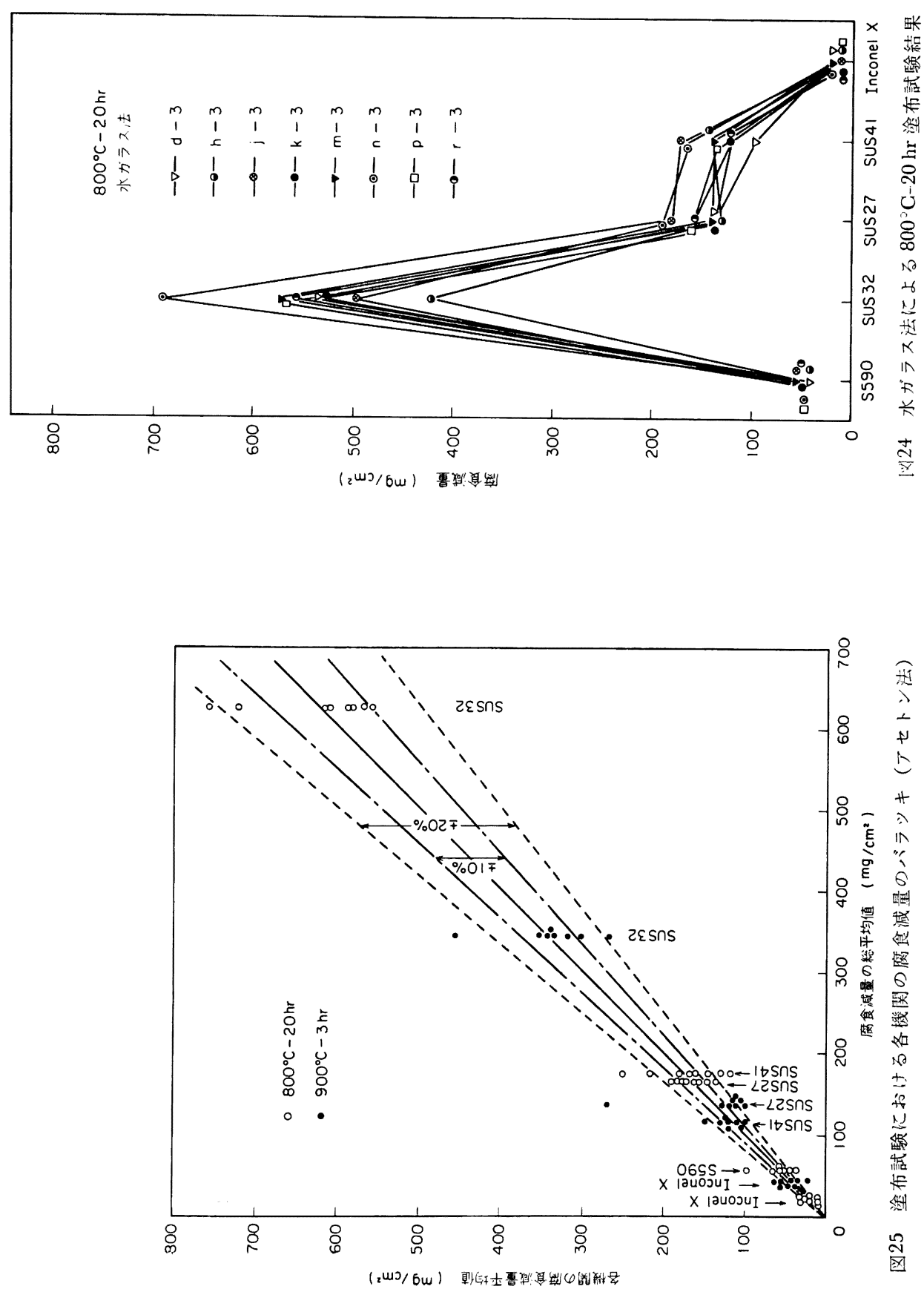

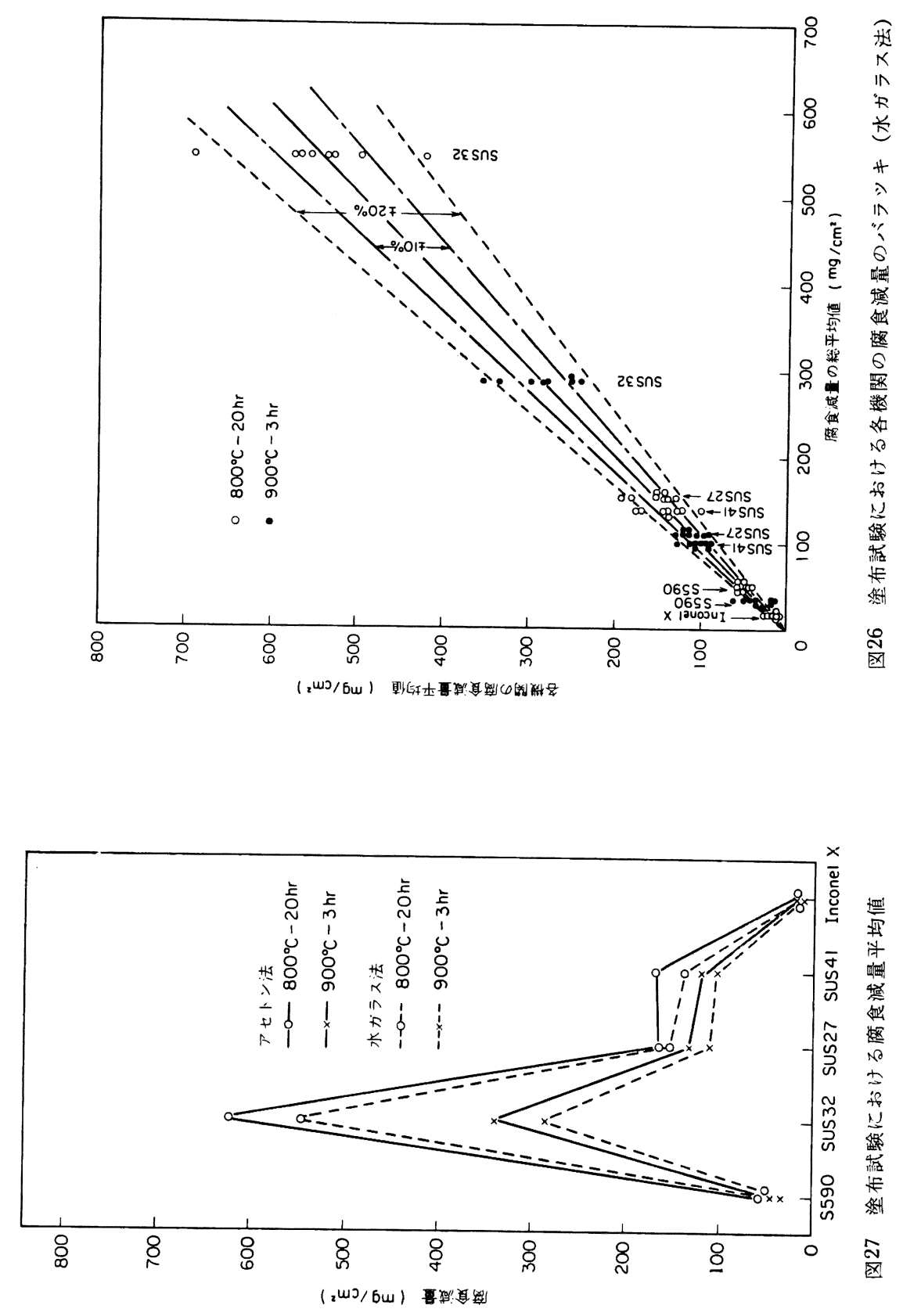


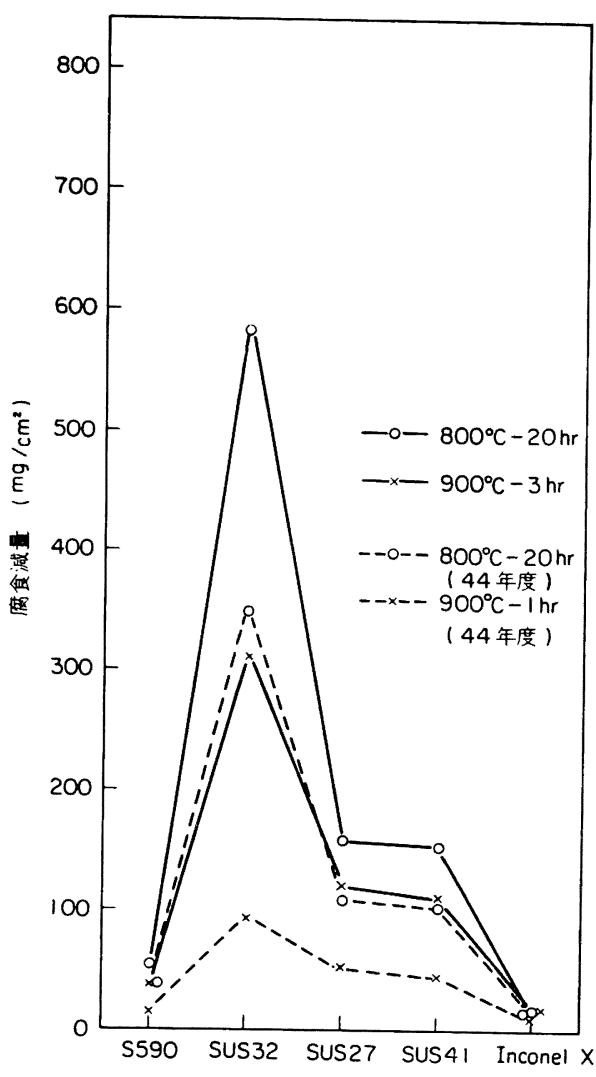

図28叙布試駼における腐食減量総平均値

に水ガラス法による塗布試験の 結果をとりまとめて示 す. 図中の應食減量の值はいずれも 3 個のデータの平均 值である。これらをみると，各機関ごとの腐食減量のひ らきは試験条件を細かく統一したために，アセトン法の $800^{\circ} \mathrm{C}-20 \mathrm{hr}$ 試験における SUS 41 (図 22) を除いて比 較的少ない. SUS 32 の腐食減量に大きなひらきがある ようにみえるが，これはSUS 32 の腐食減量そのものが 非常に多いためで，平均值に対する割合をとつてみると 図 25 および図 26 に示すようにこの合金がとくに不揃 いであるとはいえない。

つぎに図 27 に塗布方法別に求めた腐食減量の平均值 を示す. 塗布方法の影響をみると，アセトン法の腐食隇 量が水ガラス法に比べていずれの試験温度でもやや多く なつている. S 590 と Inconel X は腐食減量が少ない のでグラフの上からははつきりしないが，データをみる と両合金ともやはりアセトン法のほうがやや多い. 図 28 は染布方法に関係なく腐食減量の総平均を求めたもの で, 各供試材の應食減量はいずれの温度でも SUS 32》 SUS $27 \geqq S U S 41>S 590 \geqq$ Inconel X となつており，こ のような傾向は図中に破線で示した前年度の結果とも非 常によく一致している. また前年度の平均值と比べる

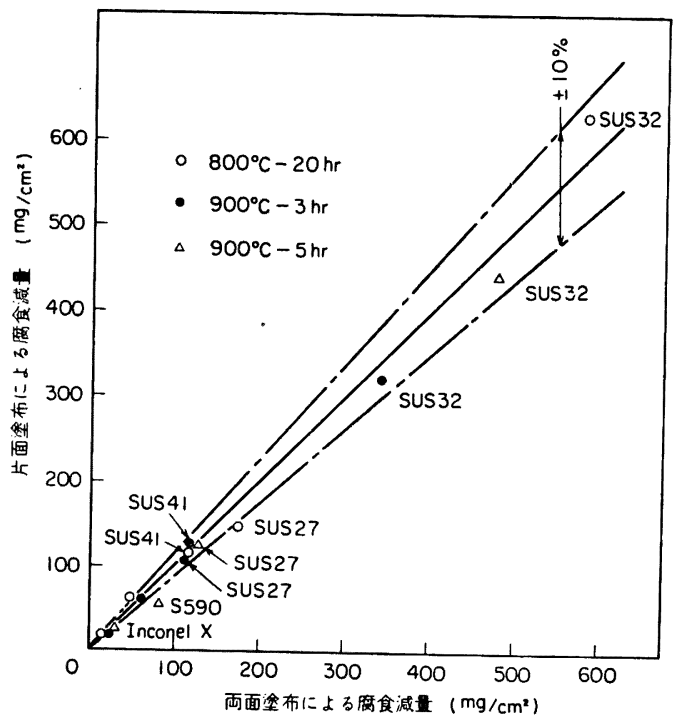

四29 両面叙布と片面塗布に打ける候食 隇量の比較 (o-3)

と, 同じ $800^{\circ} \mathrm{C}-20 \mathrm{hr}$ の場合, 前年度の方が腐食減量 が少ないが，これは主として塗布量の影響（前年度は最 高が約 $\left.20 \mathrm{mg} / \mathrm{cm}^{2}\right)$ と考えられる.

つぎに塗布方法の影響の一つとして，o-3 試験の結果 から片面塗布の場合の腐食減量を全面塗布の場合と比べ て図示すると図 29 のようになる. 図中の 2 本の一点鎖 線は両面叙布の場合の腐食隇量を基準にして片面塗布の 場合の減量がこれに対して $\pm 10 \%$ の差のある場合の限 界線である.この四から塗布量を $20 \mathrm{mg} / \mathrm{cm}^{2}$ と等しく すれば，両者はかなりよく一致することがわかる.

(2) EPMA によるスケール中の元素分布の調查

$800^{\circ} \mathrm{C}-20 \mathrm{hr}$ 試験 (f-3) 後の試験片を切断して観察す ると, Inconel X はほとんど腐食されていないが, SUS32 は最も激しく腐食され非常に小さくなつており，スケー ルは冷却中に完全にはく離している。またS 590 は腐食 減量だけからみると耐食性は良好であるが，ほかの供試 材に比べやや特異な腐食形態を示し，表面の凹凹が激し く局部的に著しい腐食をうけている. 一方 SUS 27 と SUS 41 はほぼ均一に腐食されスヶールは冷却中もはく 離せず地金に固着している. スケールが固着している SUS 27, SUS 41 および S 590 のスケールの断面顕微 鏡組織を写真 1 に示す. 写真 2 は写真 1 とほぼ同一視野 のスケールについてマイクロアナライザーによる各元㮃 の分布状態を調べた結果である. 各供試材ともスケール の大部分は $\mathrm{Fe}, \mathrm{Cr}, \mathrm{Ni}, \mathrm{Mn}$ を会むバナジウム化合物 であるが，ほぼ純粋なバナジウム酸化物がスケールと地 金の界面やスケール中に局部的に濃縮されていて，この バナジウムの漄縮個所や浱度が供試材によつてそれぞれ 異なつているようである. 


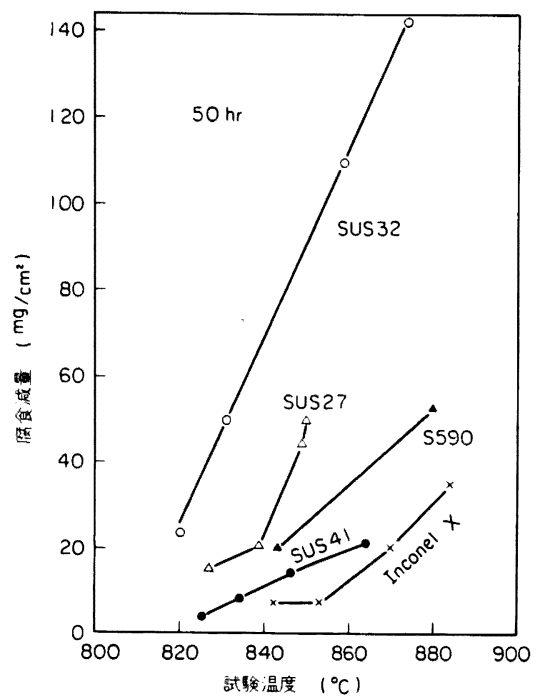

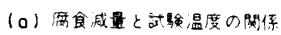

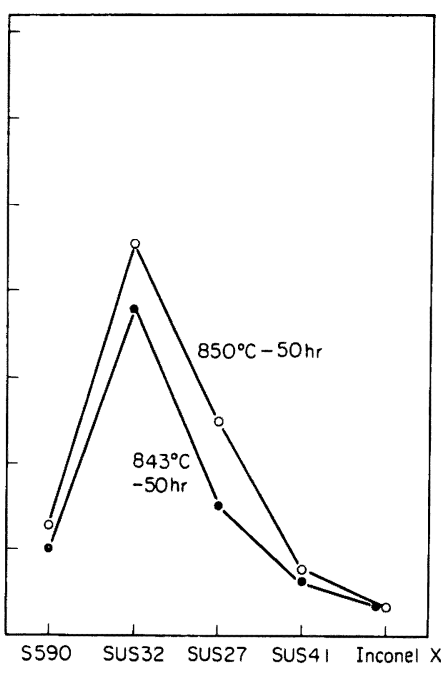

（b）各供試材の屈食隇量

困30 燃煓試鈳絬果 (o-5)

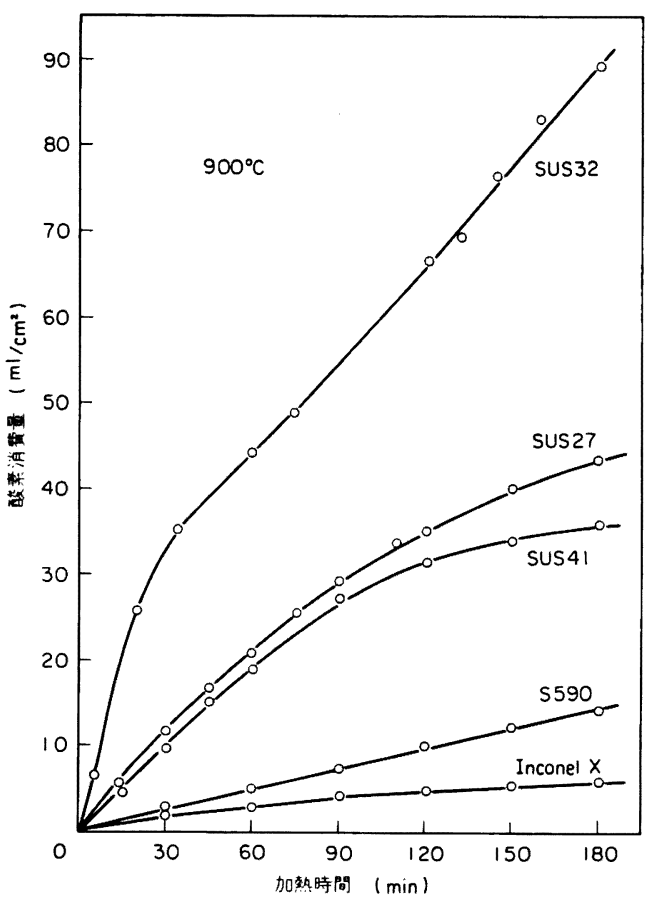

四31酸菜消費量試験結果（j-6）

\section{$3 \cdot 2 \cdot 3$ 燃焼試験}

燃焼試験の結果を図 30 に示す。 まず同図(a)の腐食 減量と試験温度との関係をみると. 腐食減量の温度依存 性がかなり大きく，かつ各供試材によつてその傾向がま ちまちである。それで一応各仆試材のデータがそろつて

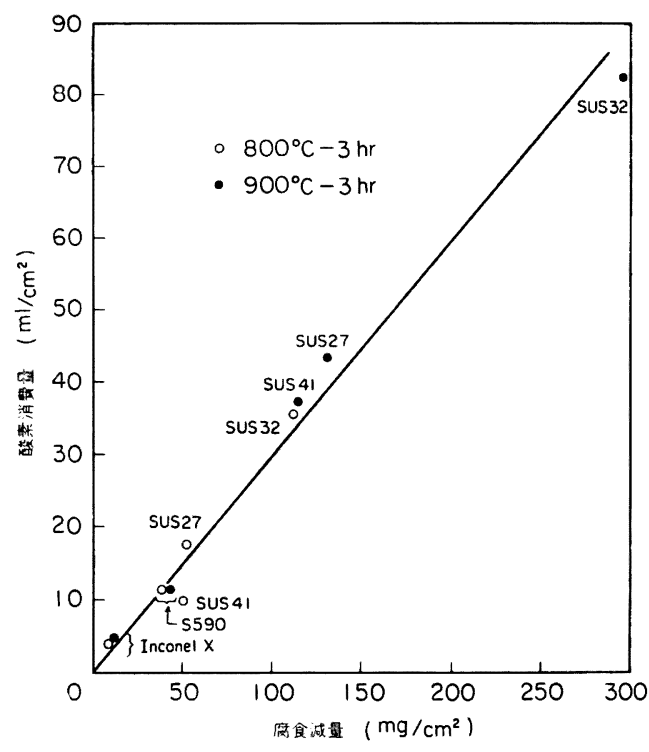

四32 $800^{\circ} \mathrm{C}$ および $900^{\circ} \mathrm{C} て ゙ ~ 3 \mathrm{hr}$ 試験後の 酸素消費量と腐食減量の関係（j-6）

いる 843 $850^{\circ} \mathrm{C}$ の温度範囲における腐食減量を比べる と同図(b)のようになる.腐食減量は多い方から SUS 32, SUS 27, S 590, SUS 41, Inconel X となつてお り, S 590 の減量が比較的多い。このような傾向は前年 度の G-5 試験にも一部に現われている。しかし o-5 試 騟の結果を, 重油組成以外はほぼ同一条件で行なわれた 前年度の O-5 試験と比べると, 後者では S 590 の腐食 減量は同一温度範囲で Inconel X とあまり差がない, 


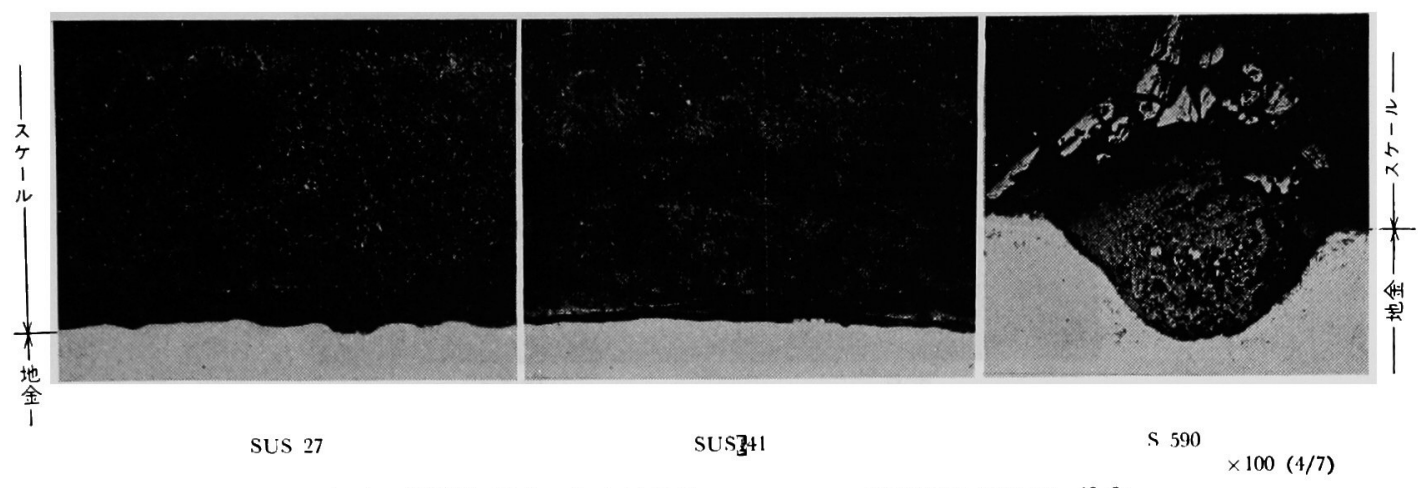

写真 $1800^{\circ} \mathrm{C}-20 \mathrm{hr}$ 泪犯試験後のスケールの断面顕微鏡組織（f-3）
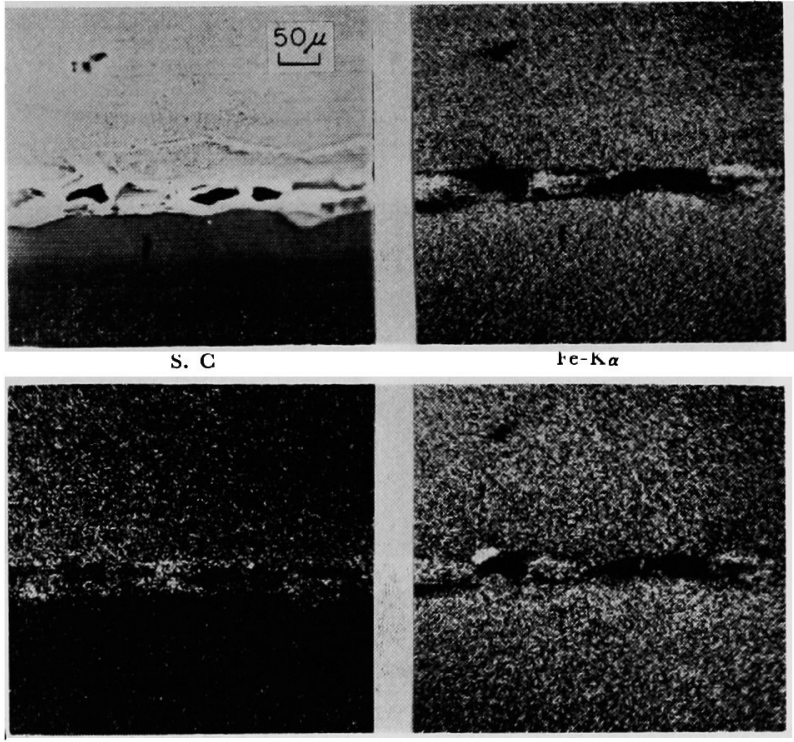

$\mathrm{V}-\mathrm{K}_{\boldsymbol{\alpha}}$

$\mathrm{Cr}-\mathrm{K} \boldsymbol{\alpha}$
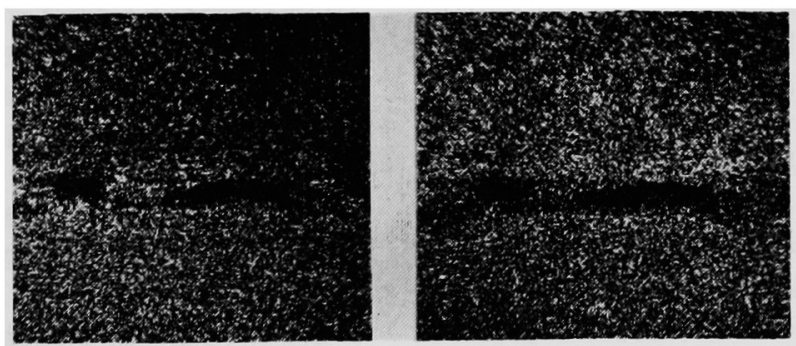

$\mathrm{Ni}-\mathrm{K} \alpha$

$\mathrm{Mn}-\mathrm{K} \alpha$

(a) SUS 27

写真 $2800^{\circ} \mathrm{C}-20 \mathrm{hr}$ 叙布試騟後のスケールの EPMAによる X 線特性像 (f-3) 

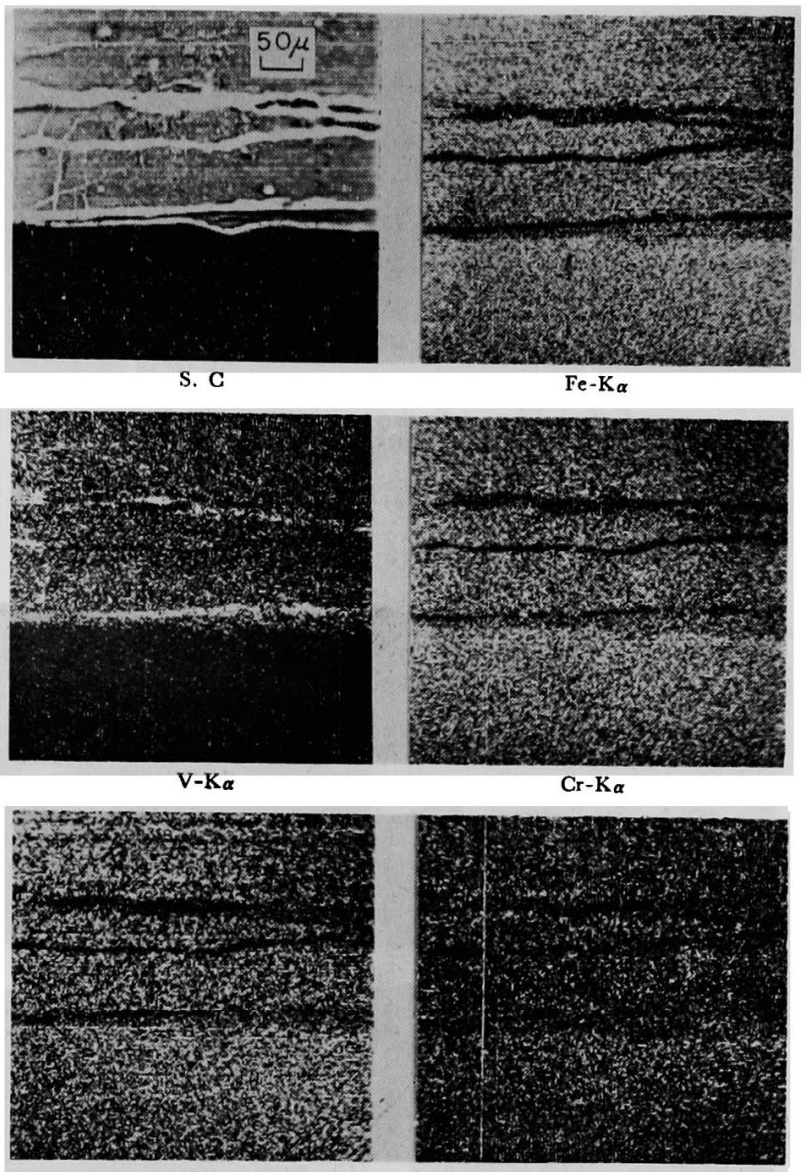

$\mathrm{Ni}-\mathrm{K} \alpha$

$\mathrm{Mn}-\mathrm{K}_{\boldsymbol{\alpha}}$

(b) SUS 41

（写真 2)

加速試験の結果と実機ないし燃焼試験の結果との対応 を明らかにすることが一応本研究の主要な研究課題の一 つと考えられるが，2 年間の共同研究の結果をみると, 燃焼試験結果そのものが試験条件によつてかなり変動す る. とくに前述のように $900^{\circ} \mathrm{C}$ 程度以上の温度になる と各供試材の腐食減量の順位の变動が著しい。これらの 点についてはさらに検討を要するが，0-5 試験とほぼ同 様の装置と条件で行なわれた燃焼試験結果 ${ }^{16) に よ る と, ~}$ AISI $310 \mathrm{~S}$ の腐食减量は約 $880^{\circ} \mathrm{C}$ でピークとなり,さ らに温度が上昇すると逆に急減しており，このような現 象は燃焼ガス中の腐食性化合物の性状变化, たとえば液 相から気相への移行などによると推論されている. とこ ろが同一条件で試験しても X-45の場合はこのような傾 向はなく，したがつてほほ $950^{\circ} \mathrm{C}$ 以上では両者の腐食 減量は逆転している. また BUCKLAND ら ${ }^{15)} は$ 同じく25 $\mathrm{Cr}-20 \mathrm{Ni}$ 鋼について 650 980 $\mathrm{C}$ の範囲で燃焼試験を 行なつているが, 腐食減量は $870^{\circ} \mathrm{C}$ 付近までは温度の
上昇とともに増加し, それ以上の温度ではあまり变わら ないかやや減少する傾向を示している. すなち $900^{\circ} \mathrm{C}$ 程度以上の高温になると, 燃焼によつて生成した腐食性 化合物の種類や性状の変化などが原因で, 比較的低温で は安定であつた腐食減量と温度との関係や各供試材の腐 食減量の順位に種々の変化を生ずるものと推定される.

したがつて最初から一定量の合成灰を試験片に塗布した りして行なう加速試験との対応も高温になるほどつきに くくなることも考えられる. 以上は主として試験温度の 影響について述べたが，燃焼灰の付着効率はガス流速の 影響をもうけやすく ${ }^{13) 17) ， ま た ~} \mathrm{PbO}$ 化合物の場合であ るが, 溶融ないし半溶融状態での付着 (粘着) 性は供試 材の種類によつてもかなり異なることが報告されてい る $^{18)}$.

それで一応これまでの燃烍試験結果を，試験温度が $880^{\circ} \mathrm{C}$ 程度以下の場合についてみると, 腐食減量の順位 は前年度の G-5 (平均値) と K-5 および O-5 試験で 


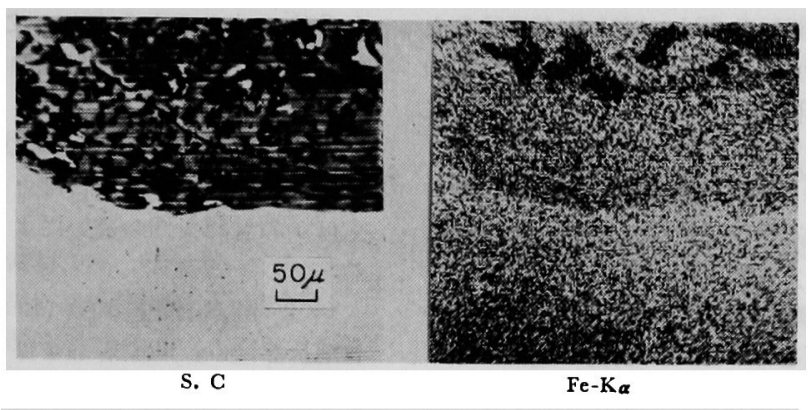

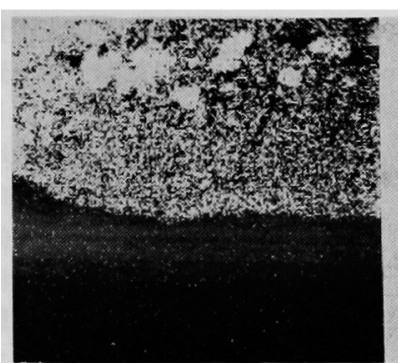

$\mathbf{V}-\mathbf{K}_{\boldsymbol{\alpha}}$

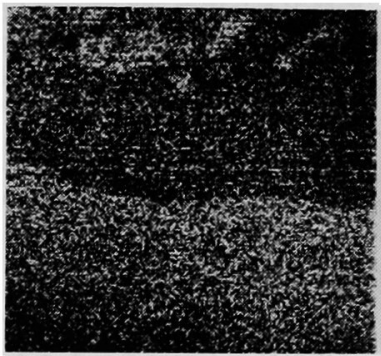

$\mathrm{Ni}-\mathrm{K}_{\boldsymbol{\alpha}}$

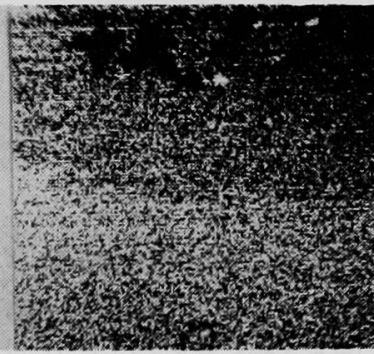

$\mathrm{Cr}-\mathrm{K}_{\boldsymbol{\alpha}}$

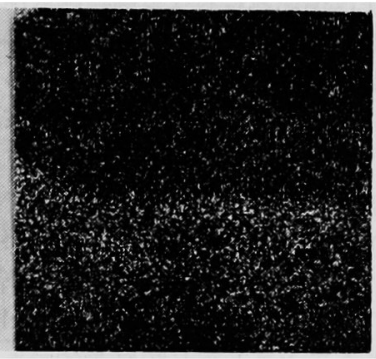

$\mathrm{Mn}-\mathrm{K}_{\alpha}$

(c) S 590

(写真 2)

は SUS 32, SUS 27, SUS 41, S 590, Inconel X であ り, 本年度の o-5 試験では上述のように S 590 の減量 が多少多めになつている. また G-5 試験でも試験温度 によつて S 590 の減量の相対的関係に微妙な差が認めら れる。

\section{$3 \cdot 2 \cdot 4$ 酸素消費量試験}

試験片に $20 \mathrm{mg} / \mathrm{cm}^{2}$ の合成灰を塗布して行なつた酸 素消費量試験の結果の一例を図 31 に示す. m-6 試験の 結果もこれとよく一致している. つぎに $3 \mathrm{hr}$ 試験後の 酸素消費量と腐食減量の関係を求めるとたとえば困 32 のようになり, 両者はほほ比例関係にある. そして比例 定数は j-6 と m-6 の両験試において近い值となつてい る.さらに純酸素中での腐食減量と大気中における腐食 減量とを比べると, 各供試片ともほぼ等しいことが認め られた (m-6).

酸素消費量の測定は装置さえあれば比較的簡単 であ り，かつ連続的に行ないうる点が一般の試験に比べて有
利と考えられるが，酸素消費量と腐食減量が比例関係に あるなら，前者を測定することにより間接的にではある が後者を知りうることになる.

\section{4. 結言}

以上 SUS 27, SUS 32, SUS 41, S 590, Inconel X の 5 種類の共通の供試材を用い, 延べ 19 機関が参加し て, 昭和 44 年度から 45 年度にわたつて行なわれたバ ナジウムアタック試験法に関する共同研究の結果につい て概要を述べた. 今後検討すべき問題も多いが，えられ た結果の主なものをあげるとおおよそつぎのとおりであ る.

（1）全浸漬試験（44 年度 15 機関，45 年度 1 機関) では温度, 時間, 合成灰の組成を統一しても各機関のデ 一タのひらきが大きい. 各供試材の腐食減量は $900^{\circ} \mathrm{C}-$ $1 \mathrm{hr}$ 試験では S $590 \gg$ SUS $32 \gg$ SUS 27>SUS 41>Inconel X のようになり，この順位は全機関を通じてょく 
揃つている.ところが $800^{\circ} \mathrm{C}-20 \mathrm{hr}$ 試験では平均をと れば上位 3 者の順位は一応 SUS 32, S 590, SUS 27 の ようになるが, これらの間の差はわずかで各機関ごとに これらの順位がかなりまちまちである.

（2）半没瀆試験（44 年度 1 機関，45 年度 2 機関) では S 590 とUS 32 の㢈食減量が 全浸漬試験 $\left(900^{\circ}\right.$ C-1 hr）の場合に比べて大きく逆枟する. 半浸漬試験は 試験片の一部分（たとえば 1/4）が溶融灰に淡り，その 灰が絶えず試験片の表面をはい上つて腐食が進行する. すなわち灰に㳇つていない部分についてみると, 塗布試 験において灰の供給の多い場合に相当すると考えられ る、したがつて，この試験では全浸漬試験の場合に比べ て, 染布試験汇強い S 590 の腐食減量が相対的に少なく なつたと若えられる.このような傾向は浸漬深さが減少 するほど著しくなる。

（3）溶融灰の量の多少は浸漬試験の絬果に大きな影 響をあたえる、全浸清試験における㦄食減量の絶対值に 各機関ごとの大きなひらきのあるのは主としてこの影響 であると考光られる. 灰の量を大幅に変えて行なつた浸 漬試験の結果によると, 全浸漬試験における腐食隇量は 一般に灰の量が多くなるにつれて急激に減少する。これ は主として試駗片への酸素供給量の多少に因ると考えら れる. また半浸漬試験では灰の量の減少にともない腐食 隇量は全般に減少する.

(4) 染有試験 (44 年度 5 機関, 45 年度 17 機関) で はいずれの温度でも腐食隇量は SUS $32 》 S U S ~ 27 \geqq S U S$ $41>$ S $590 \geqq$ Inconel X のようになり, SUS 27 とUS 41 の腐食隇量の差が少ないこと, また S 590 が Inconel $\mathrm{X}$ に近いすぐれた耐食性を示すことなどが特徵的であ る. このような傾向は 2 年間の研究を通じてい元ること である. 45 年度は試駼条件を細かく統一したため各機 関のデータはよく揃つている. 参加機関を 2 分して水ガ ラス法とアセトン法を分担したところ，この両塗布法間 の腐食減量の差は僅少であつた、また片面塗布の結果は 塗布量を等しくすれば全面叙布の場合とよく一致する.

（5）交互浸漬試験（44 年度 2 機関）においては S 590 の腐食減量のほかの供試材に対する相対的比率は全 浸漬試験に比べれば小さく, 塗布試験に比べれば大き い.これはこの試験が塗布試験と全浸清試験の中間的性 格をもつ，あるいは叙布試験において灰の供給の多い場 合とみられるためと考えられる。なおこの試験では浸漬 と加熱のインターバルが試験結果に大きな影響をあたえ るようである.

（6）燃燒試験 (44 年度 5 機関，45 年度 1 機関)にお ける腐食減量の順位を, その变動の比較的少ない $880^{\circ} \mathrm{C}$ 程度以下の場合についてみると, 大体 SUS 32, SUS 27, SUS 41, S 590, Inconel X のようになる場合が多く, これは染布試験に打ける順位と一致する。しかしこの試 験では試験条件によつてはS 590 の腐食減量が 2 位ない
し3位に上ることもあり，このような傾向は半浸漬試

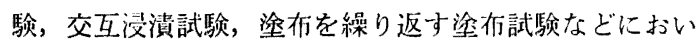
ても一部に認められる.

一方 $900^{\circ} \mathrm{C}$ 程度以上の試験温度になると, 腐食隇量 の順位は低い温度の場合ほど一定せず，同じ試駼温度で もほかの試䮖条件の藻いにより著しく恋動するようでめ る.

（7）酸素消費量試験（45 年度 2 機関）では試験片に

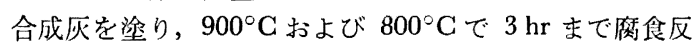

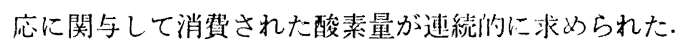
その結果, 各供試材の酸素消費量は叙布試験における腐 食減量とその順位において一致した。 また $3 \mathrm{hr}$ 試験後 の腐食減量を求めたところ, これは酸素消費量とほぼ比 例関係にあり，かつ比例定数は灰の塗布量を同じにした 2 機関の間でほぼ等しい值となつた.

（8）以上の各種の実験室的加速試験之燃烧試験との 関連性をみると, 本研究の簌围内では叙布試験㧍よび酸 素消費量試験の結果が燃焼試験結果に最も近い場合が多 いが, 燃烧試験の条件によつては半浸漬試験, 交互浸漬 試験あるいは叙布を繰り返す叙布試験などのほうがよく 一致する場合もあるようである。

これに対し全浸清試験結果は燃焼試験結果とはかなり かけ㜠れており，ことに $900^{\circ} \mathrm{C}$ の試験では $\mathrm{S} 590$ の腐 食減量が著しく多いという特異な現象がみられた。

（9）本研究における S 590 の挙動は特異である.S 590 の腐食減量は全漫漬試験ではほかの供試材に比べて 著しく大きな値を示す反面, 準布試験では Inconel X に近いきわめて小さい値を示す、また半洨漬試験, 交互 淡漬試験などではこれらの中間的な值を示す。一方燃谠 試験では大体塗布試験に近い傾向を示すが, 条件によつ ては半浸清試験などに近い場合もみられる。このような 挙動の原因についてはまだ十分明らかでないが, 各試験 法に打ける酸素供給量の多少が関係しているように思わ れる.

終わりに臨み，本共同研究に直接参加された下記の各 機関のご協力に対し感謝するとともに，本研究を進める にあたりご䩒達とご協力を頂いた委員長はじめ各分科会 の主查や幹事各位に謝意を表しをす。また共同研究幹事 の東京芝浦電気(株) の帆足純, 特殊製鋼(株)の鶴見州宏 両氏ならびに東京都立大学助手戸部省吾氏のご尽力に対 し感謝いたします。

本共同研究参加機関名（五十音順）

石川島播磨重工業(株) 技術研究所

川崎重工業(株) 技術研究所

(株) 栗本鉄工所

新日本製鉄(株) 技術研究所

主友金属工業(株) 中央技術研究所

大同製鋼 (株) 中央研究所

東京芝浦電気(株) タービン開発部 
トョタ自動車工業(株)

東京都立大学 工学部

特殊製鋼 (株)

日本鋼管(株) 技術研究所

円本ステンレス (株)

日本特殊銅 (株)

日本治金工業(株) 川崎製造所 研究部

日立金属（株）安来工場 治金研究所

(株) 日立製作所 日立研究所

三井造船 (株) 玉野研究所

三菱重工業(株) 技術本部 神戸研究所

山梨大学 教育学部

\section{文献}

1) 宮川, 帆足, 鶴見: 学振耐熱金属材料委員会研究 報告，10 (1919) 3, p. 481

2 ) 武田, 宮川: 同上, 11 (1970) 1, p. 171

3 ) 武田, 宮川: 同上, 11 (1970) 2, p. 375

4 ) 武田, 宮川: 同上, 12 (1971) 1, p. 71

$5)$ たとえば $G . W$. Cunningham and $A$. deS. Brasunas: Corrosion, 12 (1956), p. 389

6 ）宮川, 戸部：学振耐熱金属材料委員会研究報告, 11 (1970) 2, p. 367
7 ) E. Fitzer and J. Schwab: J. Berg u Hüttenmänn, Monatsh, 98 (1953), p. 1

8 ) E. Fitzer: Arch. Eisenhüttenw., 26 (1955), p. 159

9 ) E. Fitzer and J. Schwab: Corrosion, 12 (1956), p. 459

10) 小若, 諸石, 牧浦: 学振耐熱金属材料委員会研究 報告， 11 (1970) 2，p. 359

11）原田：学振耐钘金属材料委員会研究報告，12 (1971) 3, p. 327

12) A. deS. Brasunas and $N . J$. Grant: Trans. Amer. Soc. Metals, 44 (1952), p. 1117

13) $H$. Pfenninger: ASME Paper No 62-WA-188 (1962)

14) A.B. Hedley: ASME Paper No 65-WA/10-4 (1965)

15) B.O. Buckland and D.G. Sanders: Trans. Amer. Soc. Mech. Eng., 77 (1955), p. 1199

16) 石橋, 中闰, 佐藤: 日本機械学会誌, 73 (1970), p. 65

17) 井口, 吉田, 帆足: 同上, 73 (1970), p. 105

18) L.J. Danis: Paper presented at Eaton Eng. Forum, Feb., 1953 